\title{
In vitro study after exposure to the aqueous extract of Piper amalago L. shows changes of morphology, proliferation, cytoskeleton and molecules of the extracellular matrix
}

\author{
Estudo in vitro após a exposição ao extrato aquoso de Piper amalago L. mostra alterações de \\ morfologia, proliferação, citosesqueleto e moléculas da matriz extracelular \\ Estudio in vitro después de la exposición al extracto acuoso de Piper amalago L. muestra los \\ cambios en la morfología, proliferación, citoesqueleto y moléculas de la matriz extracelular
}

Vera Lucia Pereira dos Santos ORCID: https://orcid.org/0000-0002-9250-2248 Centro Universitário Internacional Uninter, Brazil E-mail: vera.s@uninter.com

Célia Regina Cavichiolo Franco ORCID: https://orcid.org/0000-0003-2525-7788

Universidade Federal do Paraná, Brazil E-mail: crcfranc@ufpr.br Ricardo Wagner

ORCID: https://orcid.org/0000-0002-9100-4757 Universidade Federal do Paraná, Brazil E-mail: ricardo.wagner@ufpr.br Caroline Dadalt Silva

ORCID: https://orcid.org/0000-0002-4594-5660 Universidade Federal do Paraná, Brazil E-mail: dadaltcarol@gmail.com

Giane Favretto dos Santos

ORCID: https://orcid.org/0000-0002-7522-7934 Universidade Federal do Paraná, Brazil

E-mail: gianefavretto@gmail.com

Regiane Stafim da Cunha

ORCID: https://orcid.org/0000-0002-7925-7698 Universidade Federal do Paraná, Brazil

E-mail: regidacunha@gmail.com

Andréa Emilia Marques Stinghen

ORCID: https://orcid.org/0000-0001-8595-5321 Universidade Federal do Paraná, Brazil E-mail: andreastinghen28@gmail.com

Luciane Mendes Monteiro

ORCID: https://orcid.org/0000-0003-2896-8147

Universidade Estadual de Ponta Grossa, Brazil E-mail: lmmonteiro@uepg.br Julia Emília Bussade

ORCID: https://orcid.org/0000-0002-8516-5888 Universidade do Mississípi, USA E-mail: bussade@olemiss.edu Jane Manfron Budel

ORCID: https://orcid.org/0000-0003-1873-2253 Universidade Estadual de Ponta Grossa, Brazil E-mail: janemanfron@ @otmail.com Iara José de Messias-Reason ORCID: https://orcid.org/0000-0002-5573-260X Universidade Federal do Paraná, Brazil E-mail: iara.reason@hc.ufpr.br

\begin{abstract}
Piper amalago L. is a medicinal plant traditionally used as a healing agent for wounds, burns, abscesses, boils, and insect bites. The current study aimed to evaluate the possible effects of the aqueous crude extract obtained from $P$. amalago leaves, in different concentrations and in different incubation times, using the in vitro model of mouse
\end{abstract}


fibroblasts (3T3). The extract was tested in different concentrations at the $24 \mathrm{~h}$ incubation time for analysis of cell viability, cytotoxicity, proliferation, cell morphology, immunostaining, adhesion and cell spreading assays, as well as to determine the hydroxyproline concentration and activity of the metalloproteinase MMP2. Morphologically, after exposure to the concentrations of 15 and $150 \mu \mathrm{g} / \mathrm{mL}$, the cells maintained the morphology, yet a greater number of cells with more expansions of the cell body and larger than the control cells were observed. The treated cell culture also showed a greater number of cells, larger cells, a greater expansion of the cell body, adherent cells spread over the substrate, and a more juxtaposed, central and spherical nucleus. The treatment induced greater cell adhesion to the polymer, fibronectin, and collagen I. Biochemical results showed a significant increase in the hydroxyproline amino acid after exposure for $96 \mathrm{~h}$. The extract did not induce loss of cell viability until the concentration reached 150 $\mu \mathrm{g} / \mathrm{mL}$, positively modulating proliferation, morphology, adhesion, degree of spreading, and organization of microfilaments. The extract also promoted a significant increase in the hydroxyproline amino acid.

Keywords: Fibroblast; Jaborandi-manso; 3T3 strain.

\section{Resumo}

Piper amalago L. é uma planta medicinal tradicionalmente usada como agente de cura para feridas, queimaduras, abcessos, furúnculos e picadas de insetos. O presente estudo teve como objetivo avaliar os possíveis efeitos do extrato bruto aquoso obtido das folhas de $P$. amalago, em diferentes concentrações e em diferentes tempos de incubação, utilizando o modelo in vitro de fibroblastos de camundongo (3T3). O extrato foi testado em diferentes concentrações no tempo de incubação de 24 horas para análise de viabilidade celular, citotoxicidade, proliferação, morfologia celular, imunomarcação, adesão e ensaios de propagação celular, bem como para determinar a concentração de hidroxiprolina e atividade da metaloproteinase MMP2. Morfologicamente, após exposição às concentrações de 15 e $150 \mu \mathrm{g} / \mathrm{mL}$, as células mantiveram a morfologia, porém foi observado um número maior de células com mais expansões do corpo celular e maiores que as células controle. A cultura celular tratada também apresentou maior número de células, células maiores, maior expansão do corpo celular, células aderentes espalhadas pelo substrato e núcleo mais justaposto, central e esférico. O tratamento induziu maior adesão celular ao polímero, fibronectina e colágeno I. Os resultados bioquímicos mostraram um aumento significativo no aminoácido hidroxiprolina após exposição por 96 h. O extrato não induziu perda de viabilidade celular até a concentração atingir $150 \mu \mathrm{g} / \mathrm{mL}$, modulando positivamente a proliferação, morfologia, adesão, grau de disseminação e organização dos microfilamentos. O extrato também promoveu um aumento significativo no aminoácido hidroxiprolina.

Palavras-chave: Fibroblasto; Jaborandi-manso; Linhagem 3T3.

\section{Resumen}

Piper amalago L. es una planta medicinal utilizada tradicionalmente como agente cicatrizante de heridas, quemaduras, abscesos, furúnculos y picaduras de insectos. El presente estudio tuvo como objetivo evaluar los posibles efectos del extracto crudo acuoso obtenido de las hojas de $P$. amalago, en diferentes concentraciones y en diferentes tiempos de incubación, utilizando el modelo in vitro de fibroblastos de ratón (3T3). El extracto se probó a diferentes concentraciones en el tiempo de incubación de 24 horas para el análisis de viabilidad celular, citotoxicidad, proliferación, morfología celular, inmunotinción, ensayos de adhesión y propagación celular, así como para determinar la concentración de hidroxiprolina y la actividad metaloproteinasa de MMP2. Morfológicamente, tras la exposición a concentraciones de 15 y $150 \mu \mathrm{g} / \mathrm{mL}$, las células mantuvieron su morfología, pero se observó un mayor número de células con más expansiones del cuerpo celular y más grandes que las células control. El cultivo celular tratado también mostró un mayor número de células, células más grandes, mayor expansión del cuerpo celular, células adherentes difundidas sobre el sustrato y núcleos más yuxtapuestos, centrales y esféricos. El tratamiento indujo una mayor adhesión celular al polímero, fibronectina y colágeno I. Los resultados bioquímicos mostraron un aumento significativo en el aminoácido hidroxiprolina después de 96 h de exposición. El extracto no indujo pérdida de viabilidad celular hasta que la concentración alcanzó $150 \mu \mathrm{g} / \mathrm{mL}$, modulando positivamente la proliferación, morfología, adhesión, grado de diseminación y organización de los microfilamentos. El extracto también promovió un aumento significativo del aminoácido hidroxiprolina.

Palabras clave: Fibroblasto, Jaborandi-manso; Linaje 3T3.

\section{Introduction}

Some plant species are popularly used in various regions of Brazil as healing agents (Piriz et al., 2014). Compounds and extracts from the aerial parts and roots of Piper species have been studied in order to elucidate their benefit in the healing process (Bastos et al., 2011; Jardim, 2011; Paco et al., 2016; Santos et al., 2020).

Piper amalago L., popularly known as jaborandi-manso, is a shrub that measures 2 to $7 \mathrm{~m}$, native from Central America and Brazil (Parmar et al., 1997; Guimarães \& Valente, 2001). It is an aromatic plant that produces essential oil (Santos et al., 2015). In Brazil, its leaves are used in traditional medicine as a healing agent for wounds, burns, abscesses, boils, 
and insect bites (SEMA, 2003; Alves et al., 2008; Bratti et al., 2013; Salehi et al., 2019). Additionally, P. amalago is an analgesic and digestive aid (Facundo et al., 2008), use to treat urinary stones and heart problems (Novaes et al., 2014). Furthermore, in Puerto Rico, the masticated leaves of $P$. amalago are put on bleeding cuts; whereas in Mexico, the HuastecoMaya tribes use $P$. amalago to treat edema, inflammations, and as an antipyretic agent (Durant-Archibold et al., 2018).

Pharmacological studies, performed with P. amalago, showed anti-inflammatory (Sosa et al., 2002; Novaes et al., 2014), antimicrobial (Carrara et al., 2012; Santos et al., 2016), schistosomicidal (Carrara et al., 2014), diuretic, anti-lithiasic, (Novaes et al., 2014), anxiolytic (Lopes et al., 2012), anti-Leishmania (Carrara et al., 2013), and healing activities (Guimarães \& Valente, 2001). Recently, the topical application of the aqueous extract, produced from P. amalago leaves, aided in the healing of a lacerated wound in the left thumb of a patient with type 2 diabetes mellitus over a period of 15 days in study by Santos et al. (2020).

Phytochemical analysis of $P$. amalago leaves showed the presence of amides, alkaloids, condensed tannins, flavonoids, and triterpenes (Domínguez et al., 1985; Carrara et al., 2013; Lopes et al., 2012; Rovani et al., 2013; Novaes et al., 2014; Santos et al., 2020). Essential oils of $P$. amalago leaves evidenced the presence of monoterpenoids and sesquiterpenoids (Carrara et al., 2010; Salehi et al., 2019).

Healing involves numerous cellular and biochemical events that interact for the regeneration of injured tissue. The healing process has three phases: inflammatory; proliferation or granulation, and remodeling or maturation (Campos et al., 2007; Peng et al., 2013; Medeiros \& Dantas Filho, 2016; Luciano et al., 2021). It is a complex process involving growth factors, cytokines and chemokines (Peng et al., 2011; Peng et al., 2013; De Mais et al., 2016). In a few hours after the injury, the inflammatory phase begins with increased vascular permeability, secretion of cytokines and growth factors, with activation of cell migration (Medeiros \& Dantas Filho, 2016).

The proliferation phase is responsible for the closing of the injury, in which epithelialization, fibroplasia and angiogenesis occur. Fibroblasts and specialized cells attract chemically attracted cells to the inflammation site in fibroplasia, proliferation, biosynthesis and secretion of the extracellular matrix components occur (Medeiros \& Dantas Filho, 2016).

The fibroblasts act in the remodeling phase producing collagen and depositing it in an organized way. The collagen produced initially is Type III collagen, and it is gradually replaced by Type I collagen (Peng et al., 2011; Peng et al., 2013; Cunha et al., 2015). Fibroblasts also produce metalloproteinase inhibitors (TIMPs). Metalloproteinases (MMPs) are enzymes that catalyze extracellular matrix proteins. Together, MMPs and TIMPs form a complex biological system that maintain extracellular matrix homeostasis (MEC) (Trengove et al., 1999; Gill \& Parks, 2008).

Metalloproteinases are enzymes that degrade proteins in the extracellular matrix. The MMP family includes approximately 25 proteins, being gelatinase B (MMP-9) and gelatinase A (MMP-2), two closely-related members of the MMP family that degrade collagen denatured or gelatins (Visse \& Nagase, 2003). In addition, metalloproteinases have important functions in several biological processes, for example, in morphogenesis, and in all stages of healing, such as tissue repair and remodeling in response to injury. In addition to these important functions, it is noteworthy that metalloproteinases are very important in structural and functional tissue maintenance, so they do not lose their normal architecture (Araújo et al., 2011).

In wound healing, the main effects induced by the active principles present in plant extracts are those that have antimicrobial, and antioxidant activities, as well as those that induce cell proliferation, angiogenesis; in addition to those activities that contribute to the increase in collagen production (Budovsky et al., 2015).

Considering the traditional uses of leaves of $P$. amalago as a healing agent, the present study aimed to evaluate the possible effects of the aqueous crude extract obtained from $P$. amalago leaves on cell viability, cytotoxicity, proliferation, cell morphology, immunostaining, adhesion, and cell spreading assays. In addition, this study aimed to determine the 
hydroxyproline concentration and activity of the metalloproteinase MMP2, using an in vitro model of mouse fibroblasts (3T3) in different concentrations and incubation times, in order to indicate a possible validation of its popular use as a healing agent.

\section{Methodology}

To carry out this study, a quantitative methodology was used in an experimental model (Pereira et al., 2018).

\subsection{Plant material}

Aerial vegetative parts of Piper amalago L., Piperaceae, were collected in Curitiba, Paraná (24 $18^{\circ}$ S and $49^{\circ} 37^{\prime}$ W), in May 2016. The vegetal material was identified by a taxonomist and compared with the voucher specimens deposited in the Municipal Botanical Museum of Curitiba, and was registered under number 71947.

The access to the plant material was permitted and licensed by Genetic Heritage Administration Council (CGEN/SISGEN) and was registered under number A14F6AF.

\subsection{Obtaining the aqueous extract}

The aqueous extract of the leaves of P. amalago was obtained according to the methodology described by Viana et al. (2006). The dried leaves were ground for 30 seconds; and then, $75 \mathrm{~g}$ of crushed material were mixed in $500 \mathrm{~mL}$ of distilled water for homogenization under agitation for $1 \mathrm{~min}$. The mixture was stored in glass containers kept at rest for $24 \mathrm{~h}$ at $5^{\circ} \mathrm{C}$. After the cooling period, the liquid extract was filtered to remove residues and particulate material.

\subsection{Obtaining the lyophilized product}

The aqueous extract was frozen at $-65^{\circ} \mathrm{C}$, after being subjected to negative pressure (vacuum), to remove the water by sublimation. The product obtained has a porous structure free of moisture, capable of being reconstituted in water. A Virtis SP Scientifica freeze dryer, BenchTop Pro 8L - XL70 model, was used (Viana et al., 2006).

\subsection{Cell culture}

3T3 mouse fibroblasts (ATCC® CRL-1658TM) were maintained in Dulbecco's Modified Eagle's Medium - DMEM, supplemented with $10 \%(\mathrm{v} / \mathrm{v})$ fetal bovine serum (FBS), $10 \mathrm{mM}$ Hepes, $0,25 \mu \mathrm{g} / \mathrm{mL}$ penicillin-streptomycin in $0,85 \%$ saline, $3.7 \mathrm{~g} / \mathrm{L}$ sodium bicarbonate at $37^{\circ} \mathrm{C}$ in $5 \% \mathrm{CO}_{2}$ in humidified atmosphere (George et al., 2010).

\subsection{Cell viability, cytotoxicity and proliferation assays}

3T3 cells were exposed to the aqueous extract of $P$. amalago, in a time-dependent concentration. Cell viability, cytotoxicity and proliferation were measured using neutral red as described by Borenfreund and Puerner (1985), MTT (Thyazolyl Blue Tetrazolium Bromide), as described by Mosmann (1983) and Crystal Violet, Crystal Violet Gillies et al. (1986) assays, respectively. All experiments were compared to cells in the absence of aqueous extract of $P$. amalago (control condition).

\subsection{Cell morphology}

Cell morphology was analyzed by light microscopy (LM) and scanning electronic microscopy (SEM). Cells (1×104) cultured in 24-well plates over glass coverslips (Corning), exposed or not for $24 \mathrm{~h}$ to 15 and $150 \mu \mathrm{g} / \mathrm{mL}$ aqueous extract of $P$. amalago, were fixed in $2 \%$ paraformaldehyde (Electron Microscopy Sciences, Washington, NY, USA), for 30 min, at $22^{\circ} \mathrm{C}$, washed with PBS, dehydrated in an ethanol series and stained with hematoxylin and eosin. Coverslips were mounted in 
Entelan ${ }^{\circledR}$ and examined by LM. For SEM, cells were fixed for $1 \mathrm{~h}$ in Karnovski solution (2\% glutaraldehyde (Electron Microscopy Sciences, Washington, NY, USA), $4 \%$ paraformaldehyde, $\mathrm{CaCl}_{2} 1 \mathrm{mM}$ in sodium cacodylate buffer $0.1 \mathrm{M}$ (Merck). Washed and post-fixed in 1\% osmium tetroxide (Electron Microscopy Sciences, Washington, NY, USA). Washed in sodium cacodylate buffer $0.1 \mathrm{M}$ for $1 \mathrm{~h}$ (in the dark at room temperature) and then dehydrated using increasing ethanol concentrations. The samples were dried to critical point and metallized using gold. Images were acquired on TESCAN VEGA3 LMU microscope of UFPR Electronic Microscopy Center (Biscaia et al., 2017).

\subsection{Fluorescence cytochemistry assays}

Cells $\left(1 \times 10^{4}\right)$ were grown on 13-mm-diameter glass coverslips in 24-well plates (TPP, Trasadingen, Switzerland) and were exposed or not (the negative control) for $24 \mathrm{~h}$ with 15 and $150 \mu \mathrm{g} / \mathrm{mL}$ aqueous extract of $P$. amalago. Cells were then rapidly washed with PBS and fixed with 2\% paraformaldehyde (Electron Microscopy Sciences, Hatfield, PA, USA) in PBS for $30 \mathrm{~min}$ at $22^{\circ} \mathrm{C}$, subsequently washed with PBS. For confocal microscopy, marking of cell surface carbohydrates, cells were incubated for $1 \mathrm{~h}$ with Lectin WGA conjugated to FITC $(4 \mathrm{mg} / \mathrm{mL})$ in the presence of $1 \%$ BSA in PBS at room temperature. The cell's cytoskeleton was marked with Alexa Fluor ${ }^{\circledR} 546$ Faloidina- (1:500 in 0,01\% de saponin-PBS) for 30 min at $22^{\circ} \mathrm{C}$. After, cells were washed three times with PBS. For all nuclear fluorescent using Fluoromount-G® mounting medium with DAPI (Electron Microscopy Sciences, Cat. 17984-24, Hatfield, PA, USA). Images were acquired using the laser scanning confocal electron microscopy A1R MP+ microscope (Nikon Instruments Inc, Tokyo, Japan) (Biscaia et al., 2017).

\subsection{Adhesion and cell spreading assay}

Tissue culture plates ( 24 wells, Costar Corp., Cambridge, MA) were coated for $2 \mathrm{~h}$ with fibronectin and collagen Type I $\left(10 \mu \mathrm{g} / \mathrm{mL}\right.$ in PBS). Non-adhesive substrate was prepared by coating the wells with $1 \%$ BSA (Sigma) for 60 min at $37^{\circ} \mathrm{C}$. Plates were washed with PBS and blocked with 1\% BSA in PBS for $1 \mathrm{~h}$. Cells exposed or not (the negative control) for $24 \mathrm{~h}$ with 15 and $150 \mu \mathrm{g} / \mathrm{mL}$ aqueous extract of $P$. amalago were suspended ( $5 \times 10^{5}$ cells in $0.5 \mathrm{~mL}$ medium) and allowed to attach to the substrate for $1 \mathrm{~h}$ at $37^{\circ} \mathrm{C}$ under $5 \%$ atmosphere $\mathrm{CO}_{2}$. Following incubation, unattached cells were removed by washing with PBS. Attached cells were fixed in methanol for $20 \mathrm{~min}$, stained with $0.8 \%$ crystal violet (Sigma) dissolved in $20 \%$ ethanol and washed five times in PBS. Cells were photographed with an inverted microscope (Nikon TE-300). The dye was eluted with $50 \%$ ethanol in $0.1 \mathrm{M}$ sodium citrate, $\mathrm{pH} 4.2$ and the optical density measured at $540 \mathrm{~nm}$. The degree of spreading was determined based on the images, using the program Image J Fiji Software, taking as parameter the nucleus area $\mathrm{x}$ cytoplasmic area ratio (proportion of the cell body expansion) (Nowatzki et al., 2010).

\subsection{Determination of hydroxyproline concentration}

3 T3 cells were plated on circular coverslips within 24 well-plates. Subsequently, 15, 50 and $150 \mu \mathrm{g} / \mathrm{mL}$ of the crude aqueous extract of $P$. amalago were treated for $96 \mathrm{~h}$. The supernatant was removed and the cells were subjected to alkaline hydrolysis with $\mathrm{NaOH}(10 \mathrm{M})$ at $80^{\circ} \mathrm{C}$ for $20 \mathrm{~min}$, and then the hydrolysate was oxidized with chloramine T. Finally, Ehrlich's reagent was added, which complexed hydroxyproline in a colorimetric reaction, with the intensity of coloration being proportional to the amount of hydroxyproline tissue. Absorbance was measured at $550 \mathrm{~nm}$ (Soley et al., 2016).

\subsection{Quantification and activity of MMP2 metalloproteinase}

3 T3 cells were plated on circular coverslips within 24-well-plates. Subsequently, 15,50 and $150 \mu \mathrm{g} / \mathrm{mL}$ of the crude aqueous extract of $P$. amalago leaves were treated for $96 \mathrm{~h}$. The supernatant was removed and used for the evaluation of MMP2 metalloproteinase quantification and activity. 


\subsection{Protein concentration}

The cell culture supernatant was concentrated from $6 \mathrm{~mL}$ to $100 \mu \mathrm{L}$ of volume in a SavantTM SPD1010 SpeedVac. To this volume, $400 \mu \mathrm{L}$ of methanol was added, followed by homogenization and centrifugation at 11,000 rpm for $15 \mathrm{~s}$. Later, $100 \mu \mathrm{L}$ of chloroform and $300 \mu \mathrm{L}$ of ultra-pure water were added, each step with homogenization and centrifugation as described above. Three phases were formed: the upper phase, which was discarded and $300 \mu \mathrm{L}$ of methanol was added; followed by homogenization; and centrifugation at 11,000 rpm for $2 \mathrm{~min}$. The protein pellet was air-dried and re-suspended with RIPA buffer ( $150 \mathrm{mM} \mathrm{NaCl}, 0.1 \%$ SDS, $0.5 \%$ sodium deoxycholate, $50 \mathrm{mM}$ Tris- $\mathrm{HCl}, \mathrm{pH} 8.0)$ to be submitted to zymography (Bradford, 1976).

\subsection{Zymography}

The samples were subjected to dosage total protein by the Bradford method and added in a sample buffer (2\% SDS, $30 \%$ glycerol, $0.01 \%$ bromophenol blue, $60 \mathrm{mM}$ Tris $\mathrm{pH}$ 6.8). The samples were loaded on $12 \%$ polyacrylamide gel containing $0.1 \%$ gelatin. After electrophoresis, the gel was washed in a $10 \mathrm{mM}$ Tris solution $(\mathrm{pH} 8.0)$ containing $2.5 \%$ Triton X-100 for SDS removal and protein renaturation. Later, the gel was incubated in a solution containing $5 \mathrm{mM} \mathrm{CaCl}_{2}, 150 \mathrm{mM} \mathrm{NaCl}$ and 1 $\mathrm{mM} \mathrm{ZnSO} 4$ for $48 \mathrm{~h}$ at $37^{\circ} \mathrm{C}$. Afterwards, the gel was stained with Coomassie Brilliant Blue R-250 and decolorized (40\% methanol, $10 \%$ acetic acid). The bands resulting from gelatin degradation were analyzed by densitometry using the Image $\mathrm{J}$ software (Bradford, 1976).

\subsection{Immunoblotting}

3T3 cells were cultured in $100 \mathrm{~mm}^{2}$ plates until reaching $80 \%$ confluence, and treated under the conditions described above. The cells were washed with ice-cold PBS and lysed with RIPA buffer, with protease inhibitor (Halt Protease and Phosphatase Inhibitor Cocktail, Thermo Fisher), and $1 \mathrm{mM}$ EDTA. The cell lysate was centrifuged at $10,000 \mathrm{~g}$ at $4^{\circ} \mathrm{C}$, and the supernatant was subjected to the determination of total proteins by Bradford method (Bradford, 1976). Equal amounts of protein were added to sample buffer ( $2 \% \mathrm{SDS}, 10 \%$ glycerol, $0.01 \%$ bromophenol blue, $0.0625 \mathrm{~mol} / \mathrm{L}$ Tris- $\mathrm{HCl} \mathrm{pH} 6.8,5 \% \beta$ mercaptoethanol), and heated at $100^{\circ} \mathrm{C}$ for $10 \mathrm{~min}$. The samples were loaded to the electrophoresis gel and then transferred to polyvinylidene difluoride (PVDF) membrane (Hybond ECL-GE Healthcare). After this, the membrane was blocked with 5\% skim milk in tris-buffered saline (TBS; $20 \mathrm{mM}$ tris, $150 \mathrm{mM} \mathrm{NaCl}, \mathrm{pH}$ 7,6) with $0.1 \%$ tween 20 for $1 \mathrm{~h}$ at room temperature. The membrane was incubated with anti-MMP-2 antibodies (Thermo Fischer Scientific Inc. 2C1-1D12; 1:500) in the block solution for $18 \mathrm{~h}$ at $4^{\circ} \mathrm{C}$. Next, the membrane was incubated with the secondary anti-mouse IgG HRP antibody (Sigma) of concentration $1 \mathrm{mg} / \mathrm{mL}$ (1:5000). The washes between the steps were done with TBS containing $0.05 \%$ tween 20 and TBS. The revelation was performed by chemiluminescence with Luminata Forte Western HRP substrate (Millipore) reagent using X-ray film. The intensity of the bands was analyzed with ImageJ software (Bradford, 1976).

\subsection{Statistical analysis}

Statistical analyses were performed by analysis of variance (ANOVA: single factor) of the data obtained. Tukey's test was also be used, allowing significant differences to be identified between groups. GraphPad software was used in these aspects. 


\section{Results}

3.1 Aqueous extract up to a concentration of $150 \mu \mathrm{g} / \mathrm{mL}$ does not induce cytotoxic action, loss of viability and induces cell proliferation.

As shown in Graph 1 for the cell cytotoxicity assay using the MTT method (A), and cell viability using the neutral red method (B), the results presented demonstrate that the aqueous extract neither induce cytotoxicity action nor loss of cell viability to a concentration of $150 \mu \mathrm{g} / \mathrm{mL}$ within $24 \mathrm{~h}$ of exposure. Using these methods, cytotoxicity and loss of viability were observed in the highest concentrations of 500 and $1000 \mu \mathrm{g} / \mathrm{mL}$, being in this last concentration, performing significantly.

Compound induced cell proliferation can be seen in the graph on cell proliferation assay (C), at all concentrations tested, the largest being $150 \mu \mathrm{g} / \mathrm{mL}$.

In the concentrations of 500 and $1000 \mu \mathrm{g} / \mathrm{mL}$, the tests were not performed because the assess impairment of cell viability (MTT and VN) proved to be cytotoxic. Thus, the cell proliferation assay was performed only at concentrations that maintained cell viability.

Graph 1. Cytotoxicity, viability and proliferation assays.

MTT

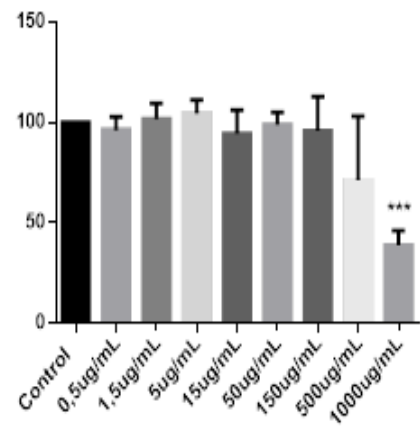

VN

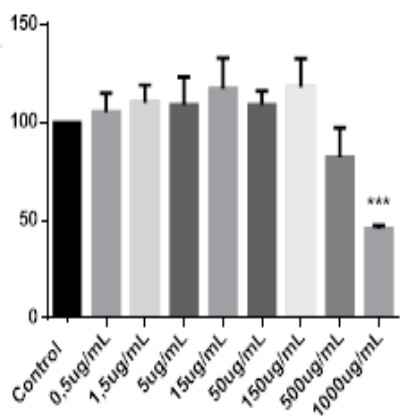

PROLIFERATION

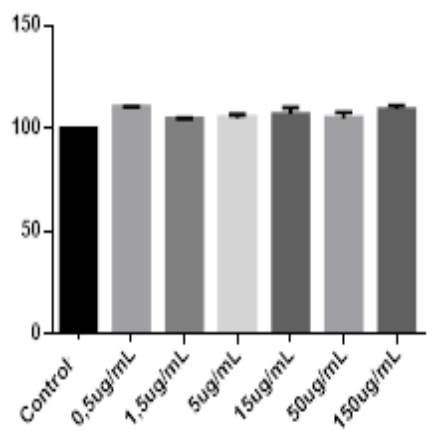

These tests were carried out in biological quadruplicates. Source: Authors.

The 3 T3 cells were exposed to the crude extract of Piper amalago in concentrations of $0.5,1.5,5,15,50,150,500$ and $1000 \mu \mathrm{g} / \mathrm{mL}$ for a $24 \mathrm{~h}$ treatment period. Letter A shows cell cytotoxicity assay, by the MTT method, letter B the cell viability assay, by the Neutral Red method and letter C the cell proliferation assay, using the Violet Crystal method.

\subsection{Aqueous extract induces morphological and ultrastructural changes}

Since the cytotoxicity, cell viability and proliferation assays showed similar results in the lowest exposure concentrations 0.5 to $150 \mu \mathrm{g} / \mathrm{mL}$, and that only in concentrations above $150 \mu \mathrm{g} / \mathrm{mL}$, the previous assays demonstrated evident cytotoxicity with impaired cell viability. In order for the other tests to be analyzed, we only standardize the concentrations of 15 and $150 \mu \mathrm{g} / \mathrm{mL}$, to be imposed for all other subsequent tests.

The morphological analysis of 3T3 control cells (CTR), cells treated with $15 \mu \mathrm{g} / \mathrm{mL}$ and with $150 \mu \mathrm{g} / \mathrm{mL}$ of crude $P$. amalago extract are shown in Figure 1 (A to I) for a period of $24 \mathrm{~h}$ of exposure.

It is noted that, in Figure 1A, controls cells observed under an optical microscope comply with the standard established for that line. They are cells with different morphologies, with characteristic cell body expansions and membrane projections. Rounded and central nucleus show contact inhibition. It can also be noted that these cells are adhered to the substrate. There is a predominance of elongated cells with clear membrane extensions, central and spherical nucleus. Treated 
cells $15 \mu \mathrm{g} / \mathrm{mL}$ (1B) and $150 \mu \mathrm{g} / \mathrm{mL}$ (1C) show a greater number of cells in cell culture. These treated cells are larger with greater expansion and degree of cell spread. Images (D to I) represent ultrastructural analysis in SEM: control cells (D and G), exposed to $15 \mu \mathrm{g} / \mathrm{mL}$ ( $E$ and $\mathrm{H}$ ) and $150 \mu \mathrm{g} / \mathrm{mL}$ (F and I), with the same exposure time. SEM results showed a greater number of cells after treatment; these are greater due to the greater expansion of the cell body. Adhered cells, were more spread over the substrate. There is a predominance of rounded cells forming cellular structures in strands, and juxtaposed cells. The pattern of cell culture was positively modulated in both morphological analyses obtained through LM and SEM.

Figure 1. Morphological examination.

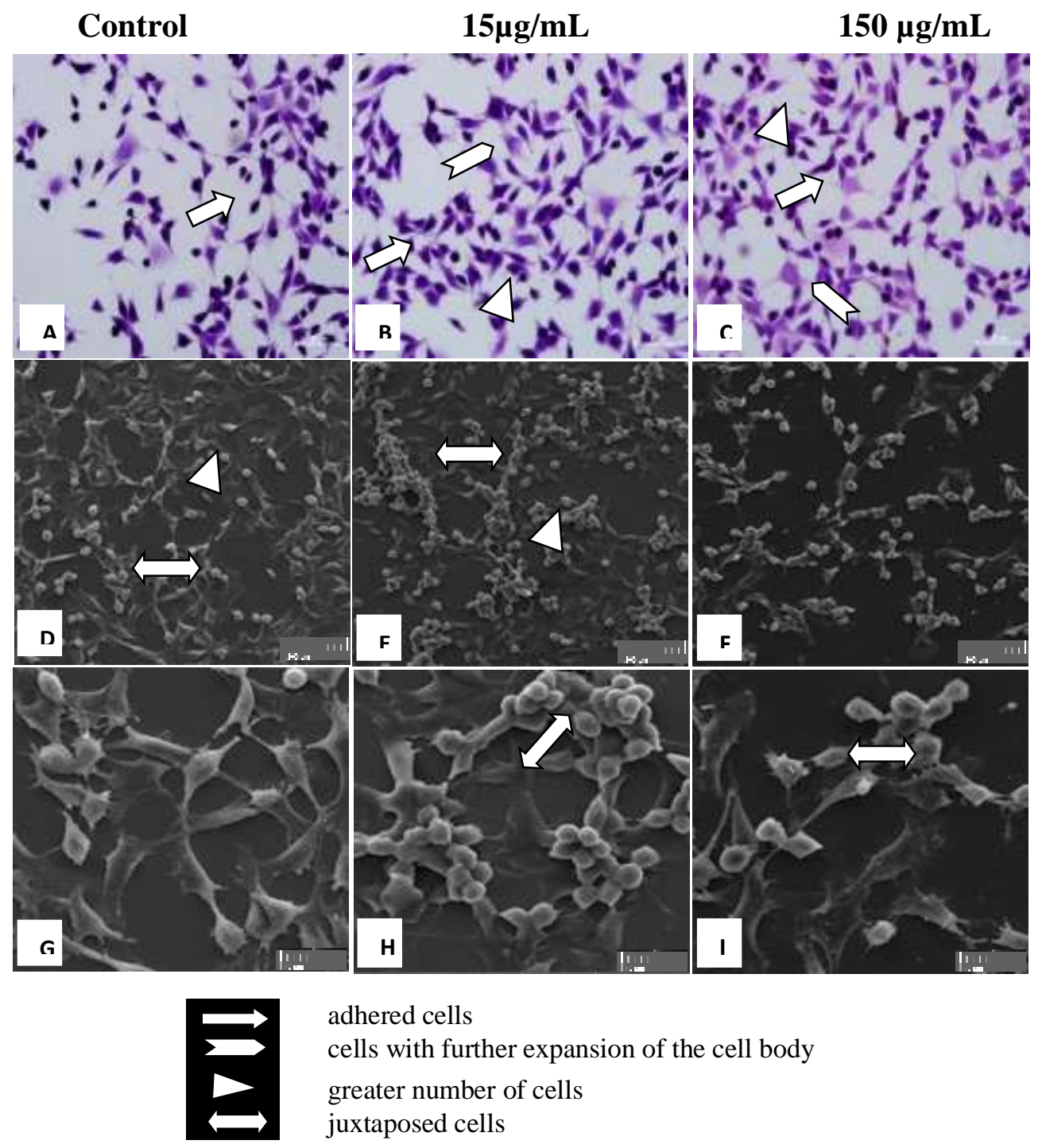

These tests were performed in quadruplicates, in two different tests. Source: Authors.

The light microscope shows in (A) 3T3 control cells (maintenance of cell culture in the absence of crude Piper amalago extract), exposed to $15 \mu \mathrm{g} / \mathrm{mL}$ (B) and $150 \mu \mathrm{g} / \mathrm{mL}$ (C), for a period of 24 hours of exposure. 400x magnification images. These tests were performed in quadruplicates, in two different tests. The scanning electron microscopy shows the control cells (D and G), exposed to $15 \mu \mathrm{g} / \mathrm{mL}$ ( $\mathrm{E}$ and H) and $150 \mu \mathrm{g} / \mathrm{mL}$ ( $\mathrm{F}$ and I) for a period of 24 hours of exposure. The images D, E and F are at 300X magnification and G, H and I images at 6000X magnification. 


\subsection{Aqueous extract induces greater cell body expansion and intercellular adhesion}

The detection of specific cell surface carbohydrates was performed using Lectin WGA conjugated to FITC. To detect the actin microfilaments, the phalloidin probe conjugated with Alexa Fluor 594 was used.

Image 2A shows $3 \mathrm{~T} 3$ control cells not imposed on treatment with crude $P$. amalago extract. Image B shows cells exposed at a concentration of $15 \mu \mathrm{g} / \mathrm{mL}$, and image $C$ shows cells imposed at a concentration of $150 \mu \mathrm{g} / \mathrm{mL}$. All of these images show glycocalyx through the immunodetection of carbohydrate (N-acetyl-glucosamine) by lectin WGA.

The (2D) image of control cells, (3E) of cells exposed to $15 \mu \mathrm{g} / \mathrm{mL}$ and (2F) of cells exposed to $150 \mu \mathrm{g} / \mathrm{mL}$ of the crude extract of $P$. amalago show the actin microfilaments of the cytoskeleton evidenced by phalloidin.

It can be observed in the immunofluorescence images that the control cells have a more elongated morphology when compared to the treated cells ( $2 \mathrm{~B}$ and $2 \mathrm{C}$ ). These cells presented with less expansion of the cell body volume (2A). In the detection for surface carbohydrates, less intensity of staining is observed for control cells. In these cells, when the nucleus/cell cytoplasm correlation is observed, they present the cell body (cytoplasm) with less expansion. Cells with different morphologies adhered to the substrate and smaller cells are observed.

Interestingly, the exposure of the cells to the aqueous extract of $P$. amalago $(2 \mathrm{~B}, 2 \mathrm{C}, 32$ and $2 \mathrm{~F}) 15$ and $150 \mu \mathrm{g} / \mathrm{mL}$ respectively show, when compared with the control cells (2A), greater expansion of the cell body. In particular, cells after exposure to $15 \mu \mathrm{g} / \mathrm{mL}$ are typically rounded, juxtaposed, maintaining intercellular adhesion forming aggregates, by cellular juxtaposition. The marking for cell surface carbohydrates shows intense dispersed marking over the entire length of the cell surface. It can be observed that treated cells showed morphological changes and the largest being juxtaposed in particular for the treatment with $15 \mu \mathrm{g} / \mathrm{mL}$.

The detection images of the actin microfilaments of the cytoskeleton showed that the control cells (2D) organize the microfilaments keeping the cells adhered to the substrate by organizing them. Smaller cells with little organization of these constituents are observed, forming few stress fibers. These cells have different morphologies.

The images $(2 \mathrm{E}$ and $2 \mathrm{~F}), 15$ and $150 \mu \mathrm{g} / \mathrm{mL}$ respectively show a clear organization of the actin microfilaments, in stress fibers occupying the entire cell cytoplasm. It is observed with this detection that the nucleus/cytoplasm ratio becomes evident that the treatment increases when compared to the cells that control the expansion of the cell body.

Similar to what was observed with the other techniques (SEM and detection of surface carbohydrates), the treatment with $15 \mu \mathrm{g} / \mathrm{mL}$ was the one that induced the greatest intercellular adhesion, being the cells more juxtaposed. In both treatments, these cells remained with a greater degree of adhesion to the substrate, spreading and an increase in the cell body. 
Figure 2. Immunomarking analysis using confocal microscopy.

Control

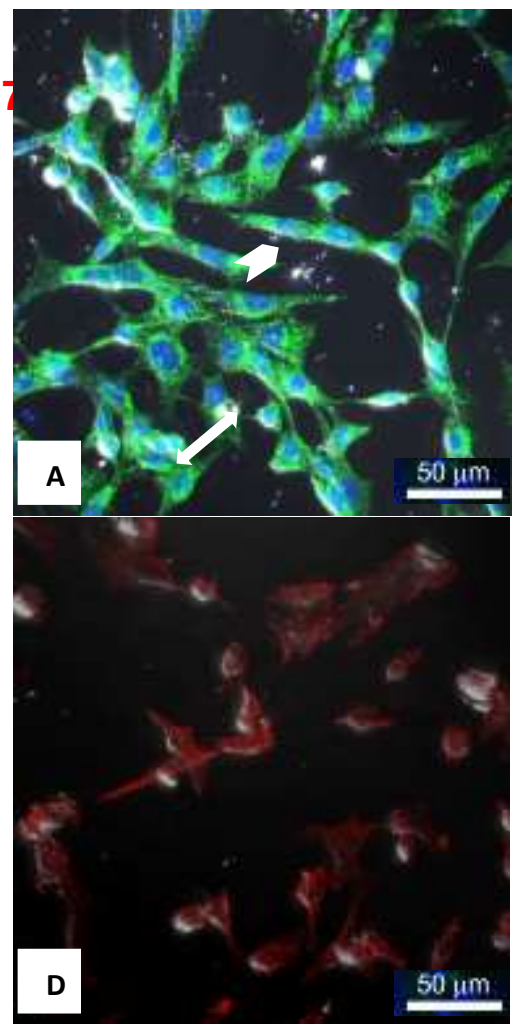

$15 \mu \mathrm{g} / \mathrm{mL}$

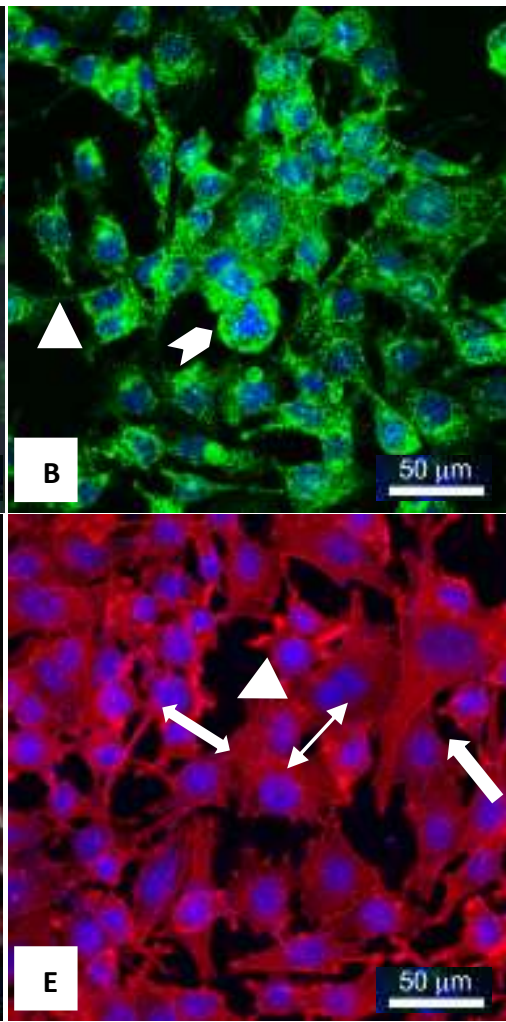

$150 \mu \mathrm{g} / \mathrm{mL}$

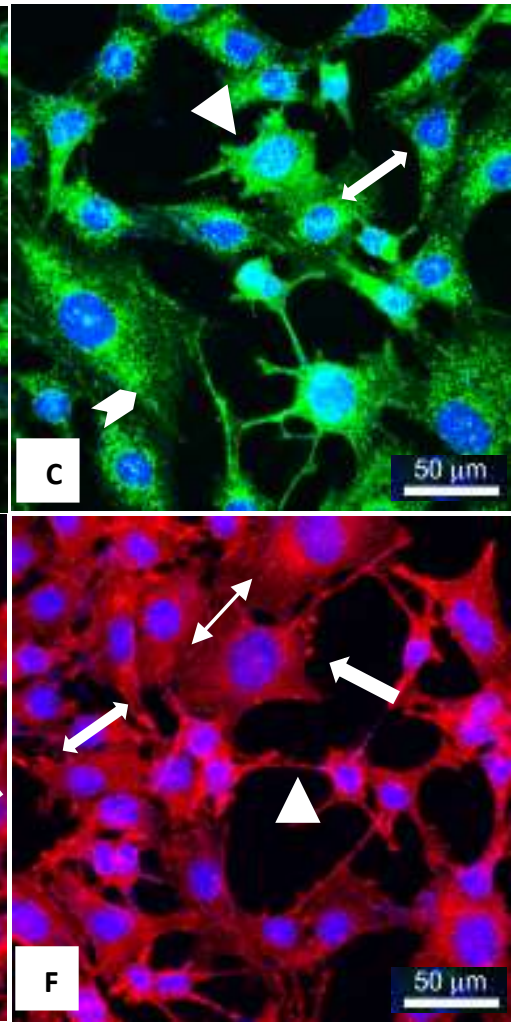

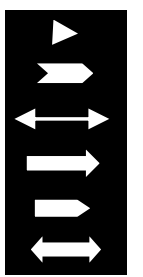

adhered cells cell surface carbohydrate detection detection of actin microfilaments cells with further expansion of the cell body greater number of cells juxtaposed cells

The experiments were carried out in triplicate in three independent experiments. The images are at 600X magnification. Source: Authors.

The images A and D represent control cells maintained in culture only in the middle presence. Images B and E are of cells exposed to $15 \mu \mathrm{g} / \mathrm{mL}$ of crude $P$. amalago extract and images $\mathrm{C}$ and $\mathrm{F}$, cells exposed to $150 \mu \mathrm{g} / \mathrm{mL}$ of extract. Exposure time of 24 hours. The images A, B and C show N-acetyl-glucosamine carbohydrates on the cell surface of the control and treated cells. Images D, E and F show detection of actin microfilaments.

\subsection{Aqueous extract induces greater cell adhesion}

Control 3T3 cells, treated with 15 and $150 \mu \mathrm{g} / \mathrm{mL}$ after $24 \mathrm{~h}$ of exposure, were imposed on the cell adhesion assay. Different MEC fibronectin (FN) was purified from fresh human plasma (obtained at the General Hospital, Federal University of Parana, Brazil) by gelatin-Sepharose affinity chromatography (Sigma, St Louis, MO, USA) as described by Engvall and Ruoslahti (1977) and Collagen I (Col. I) commercially purchased from Sigma, as well as adhesion to the polymer (substrate of the cell culture plate). For negative control of cell adhesion, bovine albumin (BSA 1\%) was used.

Graph 2 shows that in all analyzed substrates there was an increase in cell adhesion after treatment. For the treatment with the concentration of $15 \mu \mathrm{g} / \mathrm{mL}$, can be observed that there was a percentage increase of $113 \%$ adhesion to plastic and $111 \%$ adhesion to fibronectin when compared to the control. With this concentration on, both the substrates had a stimulus 
higher than that found for the concentration of $150 \mu \mathrm{g} / \mathrm{mL}$ (adhesion to plastic with an increase in adhesion of $106 \%$ and fibronectin of $107.5 \%$ in relation to the control).

It was also observed that for the concentration of $150 \mu \mathrm{g} / \mathrm{mL}$, the collagen I substrate, was the one that induced $133 \%$ greater adherence compared to the control. It is also noticed that the control cells adhere similarly to BSA and to Col. I. This result shows that the cells have less affinity for the referred substrates. Adhesion similarity of control cells was also observed for the plastic substrate and for fibronectin.

Light microscopy images of control cells (3A, 3D and 3G), treated with $15 \mu \mathrm{g} / \mathrm{mL}(3 \mathrm{~B}, 3 \mathrm{E}$ and $3 \mathrm{H})$ and $150 \mu \mathrm{g} / \mathrm{mL}$ (3C, 3F and 3I), after the cells were imposed on the cell adhesion assay (Figure 3), show that in all analyzed substrates fibronectin, $(3 \mathrm{D}, 3 \mathrm{E}$ and $3 \mathrm{~F})$ collagen $\mathrm{I}(3 \mathrm{G}, 3 \mathrm{H}$ and $3 \mathrm{I})$ and $\mathrm{BSA} 1 \%$ negative control $(3 \mathrm{~A}, 3 \mathrm{~B}$ and $3 \mathrm{C})$, after treatment the cells increased the expansion of the cell body, the cells are bigger, more adhered and spread by on the substrate.

Among all the analyzed substrates, it is observed that fibronectin is the substrate of greatest affinity for this cell line. Especially the FN substrate, both for control cells (3D), for cells treated with $15 \mu \mathrm{g} / \mathrm{mL}$ (3E) or for cells treated with 150 $\mu \mathrm{g} / \mathrm{mL}(3 \mathrm{~F})$, this matrix protein induced not only adhesion of cells to this substrate as well as a higher degree of spreading that can be observed for both treatment concentrations.

Graph 2. Cell adhesion assay of $3 \mathrm{~T} 3$ cells on different MEC proteins.

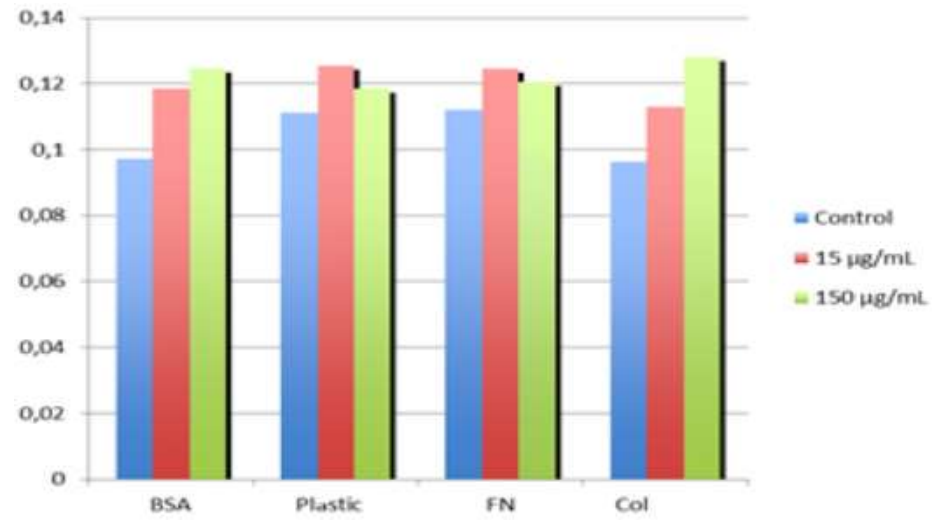

These tests were performed in quadriplicates in two independent tests. Source: authors.

The cell adhesion of control cells and treated with crude $P$. amalago extract at concentrations of 15 and $150 \mu \mathrm{g} / \mathrm{mL}$ for a $24 \mathrm{~h}$ treatment period, in 24 -well plates. A concentration of $10 \mu \mathrm{g} / \mathrm{mL}$ was used for the fibronectin and collagen I substrates. As a negative control, $1 \%$ BSA was used. 
Figure 3. Light microscopy analysis of cells imposed to the cell adhesion assay on different MEC proteins.

\section{Control $\quad 15 \mu \mathrm{g} / \mathrm{mL} \quad 150 \mu \mathrm{g} / \mathrm{mL}$}

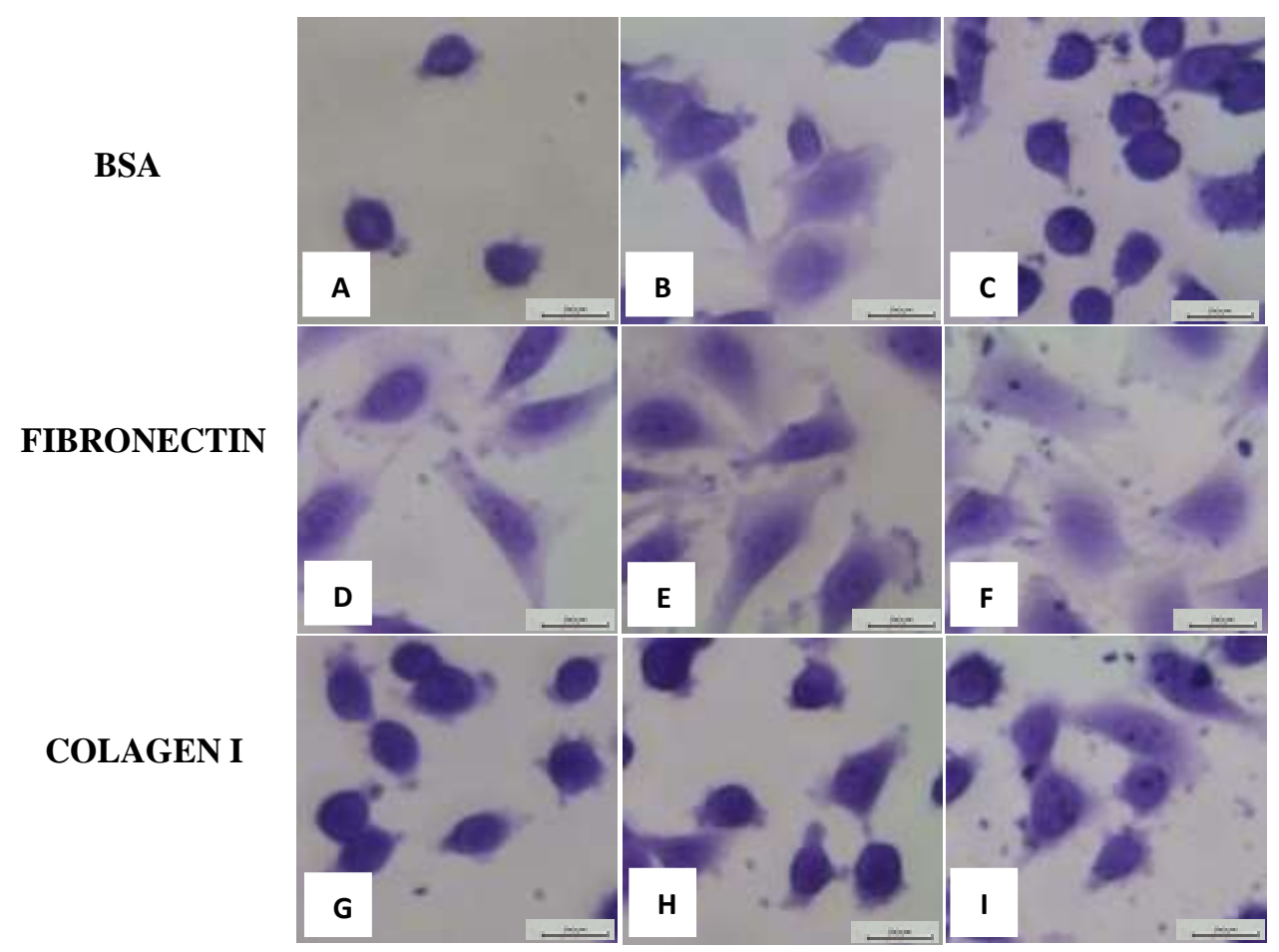

All images are in 400X magnification. Crystal Violet dye was used. These tests were performed in triplicates in two independent tests. Source: Authors.

The image A represents control cells adhered to the BSA (negative control); B cells treated with $15 \mu \mathrm{g} / \mathrm{ml}$ adhered to BSA and C, cells treated with $150 \mu \mathrm{g} / \mathrm{mL}$ adhered to BSA. Image D represents control cells adhered to the fibronectin (FN) substrate, E cells treated with $15 \mu \mathrm{g} / \mathrm{mL}$ adhered to FN and F, cells treated with $150 \mu \mathrm{g} / \mathrm{mL}$ adhered to FN. Image G shows control cells adhered to the substrate Collagen I (Col. I), H, the cells treated with $15 \mu \mathrm{g} / \mathrm{mL}$ adhered to Col. I and I, cells treated with $150 \mu \mathrm{g} / \mathrm{mL}$ adhered to Col. I.

\subsection{Aqueous extract induced an increase in hydroxyproline concentration}

The hydroxyproline concentration is used as an indirect indicator to determine the collagen content (Reddy \& Enwemeka, 1996). For the quantification of hydroxyproline, a standard curve comprising concentrations between 1.5 to 150 $\mu \mathrm{g} / \mathrm{mL}$ was constructed. $99 \% \mathrm{~N}$-acetyl hydroxyproline (Sigma 01192) was used as standard. The results obtained correspond to the average of samples from analyzes performed in quadruplicate in two independent tests (Reddy \&d Enwemeka, 1996).

As shown in Graph 3, the crude extract of $P$. amalago promotes a statistically significant increase in the hydroxyproline content in the concentrations of 15,50 and $150 \mu \mathrm{g} / \mathrm{mL}$, when compared to the control. A smaller increase was observed at concentrations of 1.5 and $5.0 \mu \mathrm{g} / \mathrm{mL}$.

Biochemical results, obtained for the determination of hydroxyproline concentration after 48 and $72 \mathrm{~h}$ of exposure, were not significant. However, after exposure for 96 h, there was a significant increase in the hydroxyproline amino acid, showing greater collagen biosynthesis by the cells after treatment. 
Graph 3. Evaluation of hydroxyproline concentration.

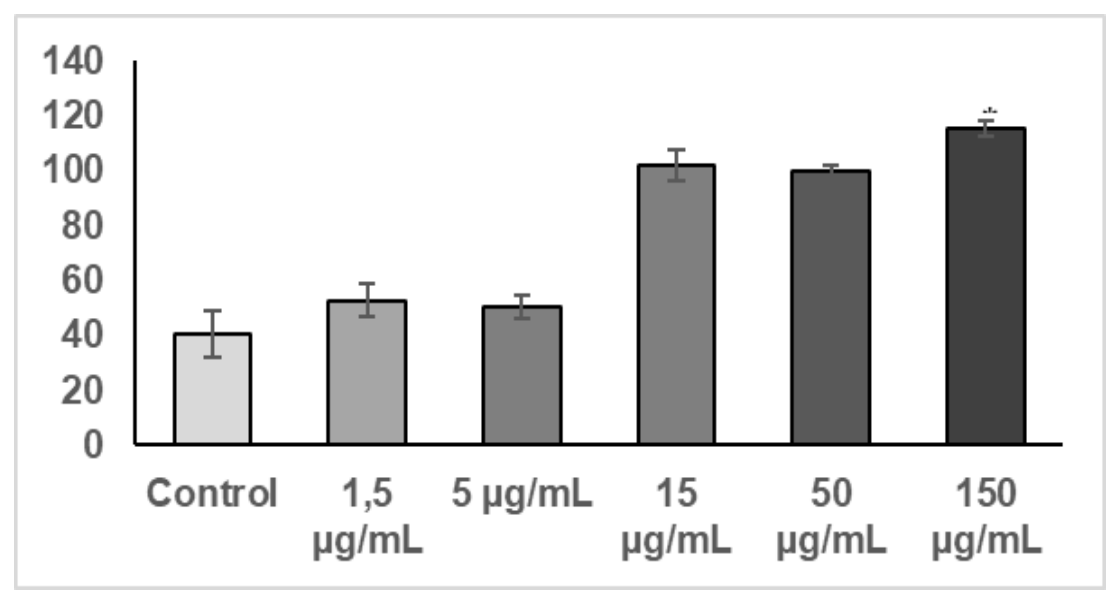

These tests were performed in quadruplicate in two independent tests. Source: Authors.

The evaluation of hydroxyproline concentration in control cells and treated with crude extract of $P$. amalago in concentrations of $1.5 ; 5.0 ; 15$ and $150 \mu \mathrm{g} / \mathrm{mL}$ for a 96 -hour treatment period. These tests were performed in quadruplicate in two independent tests.

\subsection{Quantification and metalloproteinase activity (MMP2)}

Western blotting showed no modulation of MMP2 after $96 \mathrm{~h}$ of exposure to the aqueous extract of $P$. amalago at the concentrations employed.

As shown in Graph 4, when the concentration of $15 \mu \mathrm{g} / \mathrm{mL}$ of $P$. amalago extract is used, it has a tendency to reduce the activity of metalloprotease (MMP-2) in the supernatant secreted by the cells. The concentration of $50 \mu \mathrm{g} / \mathrm{mL}$ tends to increase in both the supernatant and intracellular. The concentration of $50 \mu \mathrm{g} / \mathrm{mL}$ suggests only intracellular growth. 
Graph 4. Quantification and metalloproteinase activity (MMP2).

\section{WESTERN BLOT}

0 15 50 150

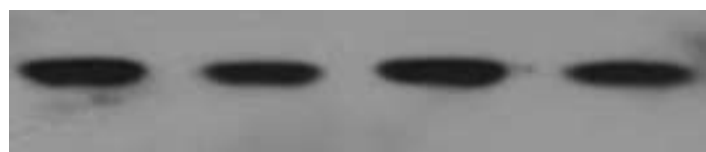

\section{MMP-2 (supernatant)}

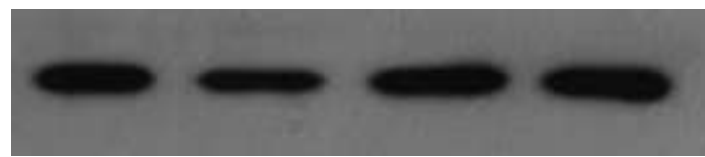

MMP-2 (cell)

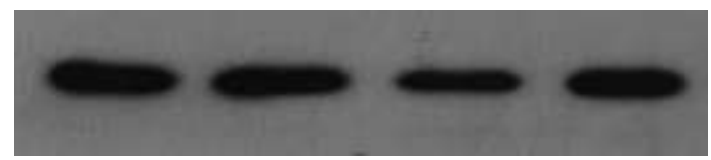

\section{$\beta$-actin}

\section{Supernatant}

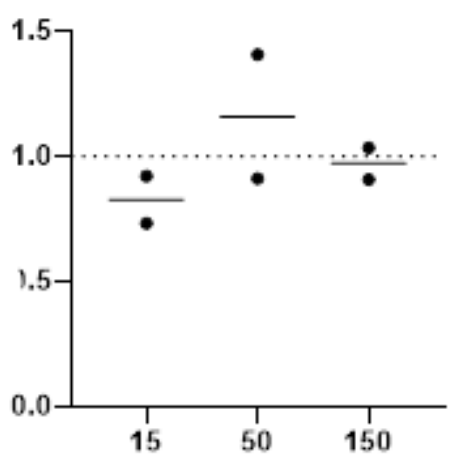

Intracellular

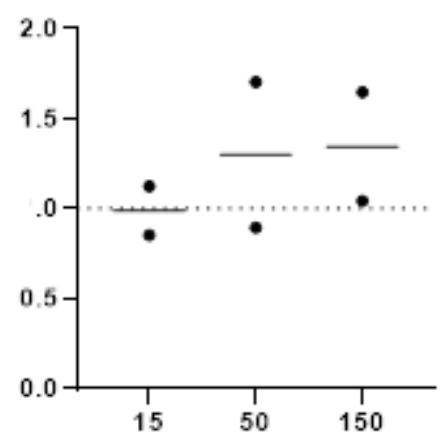

These tests were performed in quadruplicate in two independent tests. Source: Authors.

The evaluation of the quantification and activity of MMP2 in control cells and treated with crude extract of $P$. amalago at concentrations of 15,50 and $150 \mu \mathrm{g} / \mathrm{mL}$ for a treatment period of 96 hours.

\section{Discussion}

To the best of our knowledge, there is no in vitro study in the literature with $P$. amalago, using the in vitro model of mouse fibroblasts (3T3).

In wound healing, the main effects of the chemical compounds present in plant extracts are antimicrobial and antioxidant activities, as well as active components that promote mitotic activity. These active compounds contribute to cell proliferation, angiogenesis and increased collagen production and DNA synthesis (Budovsky et al., 2015).

Bioactive compounds, such as alkaloids, flavonoids, essential oils and terpenoids, have several activities, such as antimicrobial, antioxidant, anti-inflammatory and healing (Budovsky et al., 2015; Thakur et al., 2011; Tsala et al., 2013; Nascimento Júnior et al., 2020). The antimicrobial, antioxidant, anti-inflammatory and mitogenic activities of phytochemicals are essential in healing, and can positively favor one or more phases of the tissue restructuring process (Ghosh \& Gaba, 2013). As they increase the rate of wound contraction, the number of fibroblasts and the disposition of collagen fibers also increase as well as reduce the number of inflammatory cells (Nayak et al., 2013; Dogoury et al., 2015). Additionally, natural chemical 
compounds also influence the level of cytokines and levels of hydroxyproline and hexosamine (Roy et al., 2012), as well as angiogenesis (Parente et al., 2012).

Several chemical studies have been performed with $P$. amalago leaves and indicated the presence of alkaloids, condensed tannins, flavonoids and triterpenes. Piperidine, pyrrolidine amides, isobutylamides, chalcones, flavonols and phenolic compounds were also found in P. amalago (Domínguez et al., 1985; Carrara et al., 2013; Lopes et al., 2012; Novaes et al., 2014; Santos et al., 2020). In addition, Rovani et al. (2013) analyzed the crude ethanolic extract by high performance liquid chromatography (HPLC) and found the presence of vitexin and lupeol; while Carrara et al. (2012) evidenced pyrrolidine alkaloid in the leaves of $P$. amalago, using HPLC analysis of supercritical carbon dioxide and compressed propane extracts.

With regards to biological activities, vitexin and its derivatives have already been reported as potent antioxidants with anticarcinogenic and antimutagenic potential (Deladino et al., 2017). Lupeol is a triterpene found in several medicinal species and has antidiabetic, anti-inflammatory and antioxidant activities (Geetha \& Varalakshmi, 2001; Prasad et al., 2008). The treatment of wounds with lupeol-based cream effectively improved the healing process in hyperglycemic rats induced with streptozotocin with modulating effects on inflammation, oxidative stress and angiogenesis (Harish et al., 2008). In a study carried out with rat melanoma cells, lupeol inhibited cell proliferation by inducing cell differentiation (Hata et al., 2010). A pyrrolidine alkaloid showed antileishmanial activity with strong activity on promastigotes and selective action against intracellular amastigotes (Carrara et al., 2012). Amides present in the ethanol extract of $P$. amalago showed anti-hyperalgesic, antinociceptive and anti-arthritic activities in models of acute and chronic pain in rodents (Arrigo et al., 2016).

In general, tannins are used to treat wounds, burns and inflammations (Funari \& Ferro, 2005). They have the ability to promote the proliferation of epithelial cells and their migration from the periphery of the lesions, a phenomenon regulated by genes, growth factors, integrins, and matrix metalloproteinase-type enzymes (MMPs) (Hernandes et al., 2010), in addition to having high antioxidant activity (Batista et al., 2010).

In addition to stimulating healing, flavonoids have microbial and immune-modulating, anti-inflammatory, analgesic activities (Vieira et al., 2008; Coutinho et al., 2009; Gazola et al., 2014). Flavonoids also have antioxidant activity (Rovani et al., 2013; Torres et al., 2018) and antimicrobial activity (Santos et al., 2019). In antioxidant activity, flavonoids regulate the production of superoxide anions and the blood flow of the injured region, promoting angiogenesis, thus reducing free radicals in the wound (Mittal et al., 2013).

Additionally, the majority of analyses of essential oil of $P$. amalago leaves showed the prevalence of sesquiterpene hydrocarbons such as bicyclogermacrene, $\beta$-phellandrene and germacrene $\mathrm{D}$, with substantial amounts of monoterpene hydrocarbons, such as $\alpha$-pinene, and some sesquiterpenoids such as spathulenol (Salehi et al., 2019). The essential oil played important biological roles, such as antimicrobial (Moqrich et al., 2005; Santos et al., 2016) anti-inflammatory (Jeong et al., 2014; Bahi et al., 2014; Passos et al., 2014; Carneiro et al., 2017) antioxidant (Nogueira Neto et al., 2013; Santos et al., 2016; Oliveira et al., 2016), and antihyperalgesic (Carneiro et al., 2017).

Fractions obtained from stems and roots of Piper hayneanum C.DC were tested for healing activity in rats, with dorsal lesions infected with Staphylococcus aureus and Candida albicans, and showed better wound healing compared to those treated with gentamicin (S. aureus) and miconazole (C. albicans) (Bastos et al., 2011).

Bacterial contamination can increase the inflammatory phase, causing prolonged production of pro-inflammatory cytokines; if this condition persists and bacterial elimination is not achieved, the wound becomes chronic and does not heal. Therefore, the elimination of bacterial contamination in the wound microenvironment is essential for optimal wound repair (Edwards \& Harding, 2004; Guo \& DiPietro, 2010).

The aqueous extract of $P$. amalago in concentrations ranging from 0.5 to $150 \mu \mathrm{g} / \mathrm{mL}$ did not cause damage to 3T3 cells and induced cell proliferation (Graphs $1 \mathrm{~A}$ and B). 
In the case of mitosis and fibroblast migration, it is necessary to have a solid substrate that serves as a support base for the cells. The construction of this substrate is done by the lysis of inert constituents of the extracellular matrix followed by its replacement with new characteristics. Any lack of control in the lithic process, instead of benefits, can result in damage to the evolution towards repair (Balbino et al., 2005).

Since fibroblasts are the main targets in the design of therapeutic drugs, bioactive compounds that can stimulate the proliferation of fibroblasts may be able to stimulate the healing process (Singh et al., 2014), as observed in the present study. Also, the results indicated that none of the extracts exhibited cytotoxic activity in 3T3 fibroblasts. In that sense, ethnopharmacological studies have indicated that extracts obtained from species of Piper presented the ability to promote the proliferation of fibroblasts during the healing process (Panah et al., 2014; Varga et al., 2015). Khosravitabar et al. (2017) have suggested that the effects of flavonoids on fibroblast proliferation depend on their structure and concentration, and confirm that flavonoids stimulate fibroblast proliferation, especially at lower concentrations (Khosravitabar et al., 2017).

The ethanolic extract and the dichloromethane and hexane fractions obtained from the leaves of Piper arboreum Aubl. showed high toxicity at concentrations of 100 and $500 \mu \mathrm{g} / \mathrm{mL}$, with fibroblast mortality between $79 \%$ and $100 \%$ (Figueredo et al., 2014).

The hydroethanolic extract obtained from the leaves of the species Piper aduncum L. increased the proliferation and migration of human fibroblasts (HDFA), and in addition, increased the expression of growth factors (FGF, EGF and PDGF), important in the healing process. The concentrations used were $103.5 \mu \mathrm{g} / \mathrm{mL}$ after $24 \mathrm{~h}$ of treatment and $39.54 \mu \mathrm{g} / \mathrm{mL}$ after 48 h of treatment (Paco et al., 2016).

$3 \mathrm{~T} 3$ fibroblasts treated with $125 \mu \mathrm{g} / \mathrm{mL}$ of the methanolic fraction obtained from the leaves of Jatropha gossypiifolia L. exhibited an increase in migration, at $12 \mathrm{~h}$ and $24 \mathrm{~h}$, when compared to cells treated with culture media (Silva et al., 2018).

Study carried out with a fraction composed of long-chain hydrocarbons (LCHCs) obtained from the crude methanolic extract of $P$. cubeba L. fruit showed cytotoxic activity against breast cancer cells $\left(\mathrm{IC}_{50}\right.$ of $\left.2.69 \pm 0.09 \mu \mathrm{g} / \mathrm{mL}\right)$ and low toxicity against fibroblasts $\left(\mathrm{IC}_{50}\right.$ of $2.69 \pm 0.09 \mu \mathrm{g} / \mathrm{mL}$ ) (Graidist et al., 2015).

The morphological analysis of the cells suggests that the treatment with the aqueous extract in the concentrations of 15 and $150 \mu \mathrm{g} / \mathrm{mL}$ after $24 \mathrm{~h}$ of exposure, did not cause cytotoxic effects on the cells when compared to the control cells (Figures $1 \mathrm{~A}$ and B).

Fibroblasts have fusiform morphology with numerous cytoplasmic extensions, with a central and rounded nucleus, evident nucleolus and fine chromatin. They are the cells responsible for the synthesis and degradation of connective tissue (fibrous and non-fibrous) and synthesis of numerous mediators (Kanitakis, 2002; Tobin, 2006; Gartner \& Hiatt, 2017).

The fibroblast motion also shows stress fibers and lamellipodia, and changes a cell body from extended to fan-shaped or elongated (Vallenius, 2013). Filopodia and lamellipodia form immature adhesions within the substrate of the extracellular matrix, as they contain integrins and signaling molecules (Czuchra et al., 2005; Pankov et al., 2005).

These cells in vitro are linked by communicating and adhesion junctions, an indication that these cells are metabolically associated (Arenas \& Zurbarán, 2002). In the substrate adhesion tests, Graph 4 shows that for both control cells and cells treated with the crude extract of $P$. amalago, there was an increase in adhesion to fibronectin, collagen I and BSA proteins.

Through the cell adhesion assay by optical microscopy analysis, it is noted that the FN substrate was the one with the highest affinity for both control and treated cells (Figures 2 D, E and F).

Since the $\alpha 5 \beta 1$ integrin membrane receptor modulates adhesion to this substrate, possibly the treatment may be making an expressive modulation of this substrate. Integrins are responsible for many of the interactions between cells and the extracellular matrix (ECM), in addition to serving as a union between ECM and the cytoskeleton (Arenas \& Zurbarán, 2002; 
Savino et al., 2003). One ECM component is fibronectin (FN), an important molecule in migration and cell adhesion processes (Anjos \& Alvares-Silva, 2000; Kunz-Schughart et al., 2001).

Fibronectin and hyaluronic acid are the predominant components of the matrix during the early stages of wound repair (Suzuki et al., 2005).

Activated inflammatory cells are producers of reactive oxygen and nitrogen species with known lytic potential on cell membranes. Some of the inflammatory mediators, such as TNFs and TGF-b, can induce apoptosis of cells by death receptors (Moore et al., 2001).

In the present study, the results of scanning electron microscopy, optical microscopy and immunostaining show cells with cellular integrity, greater expansion of the cell body adhered to the substrate, juxtaposed, and high number of cells. These cells increased the adhesive capacity of extracellular matrix molecules, especially fibronectin, showing that the crude $P$. amalago extract does not induce loss of viability or changes in cell integrity or in cell adhesion dynamics at the evaluated times and concentrations.

The results of the carbohydrate detection assay suggest the presence of surface glycosaminoglycan scattered throughout the cell body. When compared to control cells, the treated cells show greater distribution of these glycoconjugates containing residues of $\mathrm{N}$-acetyl-glucosamine (detected using WGA) (Figures $3 \mathrm{~A}, \mathrm{~B}$ and $\mathrm{C}$ ). N-acetyl glucosamine regulates cellular responses to hormones, such as insulin; initiates a protective stress response; modulates growth and cell division capacity; and regulates gene transcription (Liu et al., 2004).

An important tool for the investigation of the cytoskeleton dynamics is the fluorescent marking of actin, using fluorescents derived from phallotoxins, as they allow the identification of whole cell culture with minimal cell disruption (Devod et al., 2001).

In the results obtained, the treated fibroblasts show a clear organization of the actin microfilaments compared to control cells. Stress fibers occupy the entire cell cytoplasm with a greater degree of adhesion to the substrate and spreading of the cell body. The treatment with $15 \mu \mathrm{g} / \mathrm{mL}$ was the one that induced the greatest intercellular adhesion (Figures $3 \mathrm{D}, \mathrm{E}$ and F).

The strength of a scar is given by the amount of collagen deposited and the way the fibers are organized. In the fiber ripening process, lysines, hydroxylysines and glycosylated lysines, constituents of the tropocollagen molecule, are oxidized (Frazier et al., 1996). In healing, when the lesion space is filled with granulation tissue, the margins move towards each other, due to the differentiation of some fibroblasts from the wound margins to myofibroblasts that have contractile capacity (Peacock Jr., 1984). In that case, the immunostaining results for the constituents of the cytoskeleton, specifically the actin microfilaments marked with the phalloidin probe, showed a clear increase in the quantity and organization of these constituents after exposure to the crude extract of $P$. amalago.

Important steps in the new phase of tissue formation are the migration and proliferation of keratinocytes and fibroblasts (Gurtner et al., 2008). The cells move, rearranging their actin framework. In order for cells to migrate, the long chain of actin must be deranged, thus being able to change shape and then migrate to other sites (Natérica, 2005). A change in shape of the actin cytoskeleton is a prerequisite for cell migration (Friedl \& Wolf, 2010).

The hydroxyproline quantification method shows that the cells treated with the aqueous extract of $P$. amalago produced a greater amount of this amino acid when compared to the control cells, with the concentration of $150 \mu \mathrm{g} / \mathrm{mL}$ being the most statistically significant ( $\mathrm{p}<0.05)$ (Graph 3).

Collagen is the most abundant protein in the body, comprising 30\% of the mass of all proteins. It is an important structural protein of connective tissues (Sandhu et al., 2012). Among the types of collagen, collagen I is the most abundant, being found mainly in the skin. This type of collagen has about 20\% proline (Pro) and 4- or 3-hydroxyproline (Krane, 2008; Gordon \& Hahn, 2010; Mienaltowski \& Birk, 2014). 
The collagen protein is directly involved in the reconstitution of the extracellular matrix and in the healing of wounds. Its deposition and collagen remodeling contribute to increase the tensile strength of the injured tissue (Vancheri et al., 2005; Sandhu et al., 2012).

Human dermal fibroblasts treated with extracts of Piper cambodianum P. Fourn. showed an increase in the expression of extracellular matrix genes, such as collagen and elastin; decreased expression of the metalloproteinase- 3 gene; a dosedependent increase in RNAm expression levels of collagen, elastin and hyaluronic acid synthase-2 (hyaluronan synthase-2); and decreased levels of expression of the metalloproteinase-1 gene. The extract also showed positive effects on wound healing in mice (Lee et al., 2016).

As shown by the results obtained in the evaluation of MMP-2 secretion by treated 3T3 fibroblasts and the gelatinolytic activity of this metalloprotease, there was no difference between the treated cells when compared to the control cells (Graph 4).

After analyzing the antitumor effects of the aqueous extracts of Aloe vera (L.) Burm.f., Annona muricata L. and black tea in three serial dilutions on the gelatinolytic activity of MMPs 2 and 9, the results suggest that the antitumor effects can be partially explained by their ability to inhibit the proteolytic activity of MMPs (Ribeiro et al., 2010).

The results obtained with the cell adhesion and spreading tests on extracellular matrix molecules showed an increase in both the degree of adhesion and the spread of these 3T3 cells after exposure to the crude extract of $P$. amalago.

Fibroblasts are cells that undergo phenotypic changes; the cytoplasm becomes bulky and has an abundant rough endoplasmic reticulum. Thus, fibroblasts secrete large amounts of collagen (Balbino et al., 2005). In the present study, the results of biochemical tests to assess hydroxyproline biosynthesis reveals an increase in the production of this molecule after treatment with $P$. amalago extract. Subtle modulation of MMPs can also be assessed.

\section{Conclusion}

According to the results found in the present study, the aqueous extract obtained from the leaves of P. amalago on the $3 \mathrm{~T} 3$ line did not prove to be cytotoxic until the concentration reached $150 \mu \mathrm{g} / \mathrm{mL}$ after $24 \mathrm{~h}$ of exposure. The cells after treatment showed greater expansion of the cell body, more juxtaposed; there is a greater number of cells with greater adhesion and spreading. The extract induced increased cell adhesion and spreading especially in fibronectin and type I collagen. The extract also induced a significant increase in the concentration of hydroxyproline (collagen production) and subtle modulation of metalloproteinase (MMP2) activity. Thus, the results revealed positive modulation in the degree of cell spreading, number of cells, adhesion, intercellular cohesion, and collagen production with promising results of the action of this compound in the healing model, in the times and concentrations studied in the $3 \mathrm{~T} 3$ fibroblast lineage.

These results endorse the ethnopharmacological use of $P$. amalago as a healing agent for wounds and burns by Central American and Brazilian communities, and may be important in the development of new healing phytomedicines.

\section{References}

Alves, E. O., Mota, J. H., Soares, T. S., Vieira, M. C., \& Silva, C. B. (2008). Levantamento etnobotânico e caracterização de plantas medicinais em fragmentos florestais de Dourados-MS. Ciência e Agrotecnologia, 32 (2), 651-658.

Anjos, A. R., \& Alvares-Silva, M. (2000). Matriz Extracelular e Leucemia. Revista Brasileira de Hematologia e Hemoterapia, 22 (3), $404-412$.

Araújo, R. V. S., Silva, F. O., Melo-Júnior, M. R., \& Porto, A. L. F. (2011). Metaloproteinases: aspectos fisiopatológicos sistêmicos e sua importância na cicatrização. Revista de Ciencias Médicas e Biológicas, 10 (1), 82-89.

Arenas, L. A. S., \& Zurbarán, C. B. (2002). La matriz extracellular: el ecosistema de la célula. Salud Uninorte, 16, 9-18. https://pdfs.semanticscholar.org/741e/7f66234e264cecac49d31df6a53c18e53fc7.pdf?_ga=2.148705079.1606144272.1597841991-2138360975.1597841991 
Arrigo, J. S., Balen, E., Lanza Junior, U., Mota, J. S., Iwamoto, R. D., Barison, A., Sugizaki, M. M., \& Kassuya, C. A. L. (2016). Antinociceptive, antihyperalgesic and anti-arthritic activity of amides and extract obtained from Piper amalago in rodents, Journal of Ethnopharmacology, $179(17), 101-109$.

Bahi, A., AL Mansouri, S., AL Memari, E., AL Ameri, M., Nurulain, S. M., \& Ojha, S. (2014). $\beta$-Caryophyllene, a CB2 receptor agonist produces multiple behavioral changes relevant to anxiety and depression in mice. Physiology \& Behavior, 135, 119-24.

Balbino, C. A., Pereira, L. M., \& Curi, R. (2005). Mechanisms involved in wound healing: a revision. Revista Brasileira de Ciências Farmacêuticas, 41(1), 614-20.

Bastos, M. L. A., Houly, R. L. S., Conserva, L. M., Andrade, V. S., Rocha, E. M. M., \& Lemos, R. P. L. (2011). Antimicrobial and wound healing activities of Piper hayneanum. Journal of Chemical and Pharmaceutical Research, 3 (4), 213-222.

Batista, J. S., Silva, A. E., Rodrigues, C. M. F., Costa, K. M. F. M., Oliveira, A. F., Paiva, E. S., Nunes, F. V. A. \& Olinda, R. G. (2010). Avaliação da atividade cicatrizante do óleo de pequi (Caryocar coriaceum Wittm) em feridas cutâneas produzidas experimentalmente em ratos. Arquivos do Instituto Biológico, 77 (3), 441-447.

Biscaia, S. M. P., Carbonero, E. R., Bellan, D. L., Borges, B. S., Costa, C. R., Rossi, G. R., Gonçalves, J. P., Melo, C. M., Lívero, F. A. R., Ruthes, A. C., Zotz, R., Oliveira, C. C., Acco, A., Nader, H. B., Chammas, R., Iacomini, M., Franco, C. R. C., \& Trindade, E. S. (2017). Safe therapeutics of murine melanoma model using a novel antineoplasic, the partially methylated mannogalactan from Pleurotus eryngii. Carbohydrate Polymers, $178,95-104$.

Bradford, M. M. (1976). A rapid and sensitive method for the quantitation of microgram quantities of protein utilizing the principle of protein-dye binding. Analytical Biochemistry, 72, 248-254.

Bratti, C., Vieira, M. C., Zárate, N. A. H., Oliveira, A. P. A., Marafiga, B. G., \& Fernandes, S. S. L. (2013). Levantamento de plantas medicinais nativas da Fazenda Azulão em Dourados-MS. Revista Brasileira de Plantas Medicinais, 15 (4), 675-683.

Budovsky, A., Yarmolinsky, L., \& Ben-Shabat, S. (2015). Effect of medicinal plants on wound healing. Wound Repair and Regeneration, 23 (2), 171-183.

Campos, A. C. L., Borges-Banco, A., \& Groth, A. K. (2007). Cicatrização de feridas. Arquivos Brasileiros de Cirurgia Digestiva, $20,51-8$.

Carneiro, N. S, Alves, C. C. F., Alves, J. M., Egea, M. B., Martins, C. H. G., Silva, T. S., Bretanha, L. C., Balleste, M. P., Micke, G. A., Silveira, E. V., \& Miranda, M. L. D. (2017). Chemical composition, antioxidant and antibacterial activities of essential oils from leaves and flowers of Eugenia klotzschiana Berg (Myrtaceae). Anais da Academia Brasileira de Ciências, 89 (3), 1907-1915.

Carrara, V. S., Souza, A., Dias Filho, B. P., \& Nakanura, C. V. (2010). Chemical composition and antifungal activity of the essential oil from Piper amalago. Latin American Journal of Pharmacy, 29 (8), 1459-1462.

Carrara, V. S., Serra, L. Z., Cardozo-Filho, L., Cunha-Júnior, E. F., Torres-Santos, E. C., \& Cortez, D. A. G. (2012). HPLC analysis of supercritical carbon dioxide and compressed propane extracts from Piper amalago L. with antileishmanial activity. Molecules, $17,15-33$.

Carrara, V. S., Cunha-Júnior, E. F., Torres-Santos, E. C., Corrêa, A. G., Monteiro, J. L., Demarchi, I. G., Lonardoni, M. V. C., \& Cortez, D. A. G. (2013). Antileishmanial activity of amides from Piper amalago and synthetic analogs. Revista Brasileira de Farmacognosia, 23 (3), $447-454$.

Carrara, V. S., Vieira, S. C. H., De Paula, R. G., \& Rodrigues, V. (2013). In vitro schistosomicidal effects of aqueous and dichloromethane fractions from leaves and stems of piper species and the isolation of an active amide from P. amalago L. (piperaceae). Journal of Helminthology, 88 (3), 1-6.

Coutinho, M. A. S., Muzitano, M. F., \& Costa, S. S. (2009). Flavonoides: potenciais agentes terapêuticos para o processo inflamatório. Revista Virtual Química, 1 (3), 241-256.

Cunha, M., Paravic, F., \& Machado, C. (2015). Alterações histológicas dos tipos de colágeno após diferentes modalidades de tratamento para remodelamento dérmico: uma revisão bibliográfica. Surgical and Cosmetic Dermatology, 7 (4), 85-292.

Czuchra, A., Wu, X., Meyer, H., Van Hengel, J., Schroeder, T., Geffers, R., Rottner, K. \& Brakebusch, C. (2005). Cdc42 is not essential for filopodium formation, directed migration, cell polarization, and mitosis in fibroblastoid cells. Journal of Cellular and Molecular Biology, 16 (10), $4473-84$.

Deladino, L., Alvarez, I., De Ancos, B., Sánchez-Moreno, C., Molina-García, A. D., \& Schneider Teixeira, A. (2017). Betalains and phenolic compounds of leaves and stems of Alternanthera brasiliana and Alternanthera tenella. Food Research International, 97, $240-249$.

De Mais, E. C. D. J., Campos, A. C. L., De Mais, F. D. J., Ratti, M. A. S., Ike, I. S. \& De Mais, R. D. J. (2016). The influence of growth factors on skin wound healing in rats. Brazilian Journal of Otorhinolaryngol, 2 (5), 512-521.

Devod, V. N., Cox, G. C., \& Roufogalis, B. D. (2001). Visualization of mitochondria in living neurons with single and two photon-fluorescence laser microscopy. Micron, 32 (7), 653-60.

Dogoury, H. G., Farahpour, M. R., \& Amniattalab, A. (2015). Comparision effect of chamomile (Chamomilla recutita) hydroethanolic extract and flaxseed oil (Linum ustatissum) alone and simultaneous administration with nitrofurazone in wound healing process. Indian Journal of Fundamental and Applied Life Science, 5 (1), 216-223

Domínguez, X. A., Verde, J., Sugar, S., \& Trevino, R., 1986. Two amides from Piper amalago. Phytochemistry, 25:239-240.

Durant-Archibold, A. A., Santana, A. I., \& Gupta, M. P. (2018). Ethnomedical uses and pharmacological activities of most prevalent species of genus Piper in Panama: a review. Journal of Ethnopharmacology, 217, 63-82.

Edwards, R., \& Harding, K. G. 2004. Bacteria and wound healing. Current Opinion in Infectious Diseases, 7 (2), $91-6$. 
Engvall, E., \& Ruoslahti, E. (1977). Binding of soluble form of fibroblast surface protein, fibronectin, to collagen. International Journal of Cancer, 20 (1), -5. 10.

Figueredo, F. G., Tintino, S. R., Brito, D. I. V., Braga, M. F. B. M., Leite, N. F., Lucena, B. F. F., Sobral-Souza, C. E., Gomez, M. C. V., \& Coutinho, H. D. M. (2014). Avaliação das potenciais atividades tripanocida e antileishmania do extrato de folhas de Piper arboreum (Piperaceae) e de suas frações. Revista de Ciências Farmacêuticas Básica e Aplicada, 35 (1), 149-154.

Facundo, V. A., Pollli, A. R., Rodrigues, R. V., Militão, J. S. L. T., Stabelli, R. G., \& Cardoso, C. T. (2008). Constituintes químicos fixos e voláteis dos talos e frutos de Piper tuberculatum Jacq. e das raízes de P. hispidum H.B.K. Acta Amazonica, 38 (4), 743-748.

Frazier, K., Williams, S., Kothapalli, D., Klapper, H., \& Grotendorst, G. R. (1996). Stimulation of fibroblast cell growth, matrix production, and granulation tissue formation by connective tissue growth factor. Journal of Investigative Dermatology, 107, 404-41.

Friedl, P., \& Wolf, K. J. (2010). Plasticity of cell migration: a multiscale tuning model. Journal of Cell Biology, 188 (1), 11-19.

Funari, C. S., \& Ferro, V. O. (2005). Uso ético da biodiversidade brasileira: necessidade e oportunidade. Revista Brasileira de Farmacognosia, 5 (2), $178-182$. gartner, L. P., \&, Hiatt, J. L. 2017. Tratado de Histologia em cores. (4. ed.) Guanabara Koogan.

Gazola, A., Freitas, G., \& Evangelista-Coimbra, C. C. B. (2014). O uso da Calendula officinalis no tratamento da reepitelização e regeneração tecidual. Revista Uningá Review, 20 (3), 54-59.

Geetha, T., \& Varalakshmi, P. (2001). Anti-inflammatory activity of lupeol and lupeol linoleate in rats. Journal of Ethnopharmacology, 76, 77-80.

George, S. E., Anderson, R. J., Cunningham, A., Donaldson, M., \& Groundwater, P. W. (2010). Evaluation of a range of anti-proliferative assays for the preclinical screening of anti-psoriatic drugs: a comparison of colorimetric and fluorimetric assays with the thymidine incorporation assay. ASSAY and Drug Development Technologies, 8 (3), 389-400.

Ghosh, P. K., \& Gaba, A. (2013). Phyto-extracts in wound healing. Journal of Pharmacy and Pharmaceutical Sciences, 16 (5), 760 - 820.

Gill, S. E., \& Parks, W. C. (2008). Metalloproteinases and their inhibitors: regulators of wound healing. The International Journal of Biochemistry \& Cell Biology, 40 (6-7), 1334-47.

Gillies, R. J., Didier, N. \& Denton, M. (1986). Determination of cell number in monolayer cultures. Analytical Biochemistry, 159 (1), 109-13.

Gordon, M. K., \& Hahn, R. A. (2010). Collagens. Cell and Tissue Research, 339 (1), 247-257.

Graidist, P., Mratla, M., \& Sukpondm, Y. (2015). Cytotoxic activity of Piper cubeba extract in breast cancer cell lines. Nutrients, 7, 2707-18.

Guimarães, E. F., \& Valente, M. C. (2001). Piperaceae - Piper. In: Reitz, R. (ed.). Flora ilustrada catarinense. Itajaí: Herbário Barbosa Rodrigues.

Guo, S., \& DiPietro, L. A. (2010). Factors affecting wound healing. Journal Dental Research, 89, 219-229.

Gurtner, G. C., Werner, S., Barrandon, Y., \& Longaker, M. T. (2008). Wound repair and regeneration. Nature, 453, 314-321.

Harish, B. G., Krishna, V., Kumar, H. S. S., Khadeer, A., Sharath, R., \& Kumaraswamy, H. M. (2008). Wound healing activity and docking of glycogensynthase-kinase-3-beta-protein with isolated triterpenoid lupeol in rats. Phytomedicine, 15, 763-767.

Hata, K., Ogihara, K., Takahashi, S., Tsuka, T., Minami, S., \& Okamoto, Y. (2010). Effects of lupeol on melanoma in vitro and in vivo: fundamental and clinical trials. Animal Cell Technology, 16, 339-44.

Hernandes, L., Pereira, L. M. S., Palazzo, F., \& Mello, J. C. P. (2010). Woundhealing evaluation of ointment from Stryphnodendron adstringens (Barbatimão) in rat skin. Brazilian Journal of Pharmaceutical Sciences, 46 (3), 431- 436.

Jardim, I. M. (2011). Reparação de feridas cutâneas de camundongos tratadas com óleo de pimenta longa, Piper hispidinervum C.DC. Revista da Universidade do Vale do Rio Verde, 9 (1), 258-276.

Jeong, H. U., Kwon, S. S., Kong, T. Y., Kim, J. H., \& Lee, H. S. (2014). Inhibitory effects of cedrol, $\beta$-cedrene, and thujopsene on cytochrome P450 enzyme activities in human liver microsomes. Journal of Toxicology and Environmental Health, 77, 1522-1532.

Kanitakis, J. (2002). Anatomy, histology and immunohistochemistry of normal human skin. European Journal of Dermatology, 12 (4), $390-399$.

Khosravitabar, F., Abrishamchi, P., Bahrami, A. R., Matin, M. M., Ejtehadi, H. \& Varasteh-Kojourian M. (2017). Enhanced cutaneous wound healing by the leaf extract of Achillea eriophora D.C. using the in vitro scratch assay. Journal of Sciences, Islamic Republic of Iran, 28 (4), 305-312.

Krane, S. M. (2008). A importância dos resíduos de prolina na estrutura, estabilidade e suscetibilidade à degradação proteolítica dos colágenos. Aminoácidos, 35 (4), 703-710.

Kunz-Schughart, L. A., Heyder, P., Schrolder, J., \& Knurchel, R. (2001). A heterologus 3 D coculture model of brest tumor cells and fibroblast to study tumor associated fibroblast differentiation. Experimental Cell Research, 66, 74-86.

Lee, H., Hong, Y., Kwon, S. H., Park. J., \& Park, J. (2016). Anti-aging effects of Piper cambodianum P. Fourn. extract on normal human dermal fibroblast cells and a wound-healing model in mice. Clinical Interventions in Aging, 29 (11), 1017-1026.

Liu, F., Iqbal, K., Grundke-Iqbal, I., Hart, G. W., \& Gong, C-X. (2004). O-GlcNAcylation regulares phosphorylation of tau: a mechanism involved in Alzheimer's disease. Proceedings of the National Academy of Sciences, 101 (29), 10804-9. 
Lopes, J. J., Marx, C., Ingrassia, R., Picada, J. N., Pereira, P., \& Ferraz, A. D. B. F. (2012). Neurobehavioral and toxicological activities of two potentially CNS-acting medicinal lants of Piper genus. Experimental and Toxicologic Pathology, 64 (1-2), 9-14.

Luciano, L. L., Sores, E. A., Garcia, J. A. D., Pereira, A. A., Miranda, A. P., Silva, D. B., Fernandes, A., Silva, T. D., Lima, S. J. F, Garcia, E. K. I., \& Lima, C. C. Utilização de óleo de moringa na cicatrização de feridas cutâneas em ratos. Research, Society and Development, 10(1), e23710110981, 2021.

Medeiros, A. C., \& Dantas Filho, A. M. (2016). Cicatrização das feridas cirúrgicas. Journal of Surgical Research, 7 (2), $87-102$.

Mienaltowski, M. J., \& Birk, D. E. (2014). Structure, physiology, and biochemistry of collagens. Advances in Experimental Medicine and Biology, 802, 5-29.

Mittal, A., Sardana, S., \& Pandey, A. (2013). Herbal boon for wounds. Int. Journal of Pharmacy and Pharmaceutical Sciences, 5 (2), 1-12.

Moqrich, A., Hwang, S. W., Earley, T. J., Petrus, M. J., Murray, A. N., Spencer, K. S. R., Andahazy, M., Story, G. M., \& Patapoutian, A. (2005). Impaired thermosensation in mice lacking TRPV3, a heat and camphor sensor in the skin. Science, 307, 1468-1472.

Moore, K. W., De Waal Malefyt, R., Coffman, R. L., \& O'Garra, A. (2001). Interleukin-10 and the interleukin-10 receptor. Annual Review of Immunology, 19, $683-765$.

Mosmann, T. (1983). Rapid colorimetric assay for cellular growth and survival: application to proliferation and cytotoxicity assays. J. Immunol. Methods 65 (1-2), 55-63. Natérica, F. (2005). Ausência de proteína altera migração de células no embrião. Ciência e Cultura, 57 (2), 1.

Nascimento Júnior, C. S., Cavalcanti, E. B. V. S, Sousa, A. P., Silva, D. F., \& Ferreira, M. D. L. Análise qualitativa do perfil químico de plantas medicinais do horto das Faculdades Nova Esperança. Research, Society and Development, 9(9), e816998033, 2020.

Nayak, S. B., Rodrigues, V., Maharaj, S., \& Bhogadi, V.S. (2013). Wound healing activity of the fruit skin of Punica granatum. Journal of Medicinal Food, $16(9), 857-861,2013$.

Novaes, A. S., Mota, J. S., Barison, A., Veber, C. L., Negrão, F. J., Kassuya, C. A., \& Barros, M. E. (2014). Diuretic and antilithiasic activities of ethanolic extract from Piper amalago (Piperaceae). Phytomedicine, 21, 523-528.

Nowatzki, J., Sene, R. V., Paludo, K. S., Veiga, S. S., Oliver, C., Jamur, M. C., Nader, H. B., Trindade, E. S., \& Franco, C. R. C. (2010). Brown spider venom toxins interact with cell surface and are endocytosed by rabbit endothelial cells. Toxicon, 56 (4), 535-543.

Paco, K., Ponce-Soto, L. A., Lopez-Ilasaca, M., \& Aguilar, J. L. (2016). Determinación del efecto cicatrizante de Piper aduncum (matico) en fibroblastos humanos. Revista Peruana de Medicina Experimental y Salud Pública, 33 (3), 438-47.

Panah, K. G., Hesaraki, S., \& Farahpour, M. R. (2014). Histopathological evaluation of Thymus vulgaris on wound healing. Indian Journal of Life Sciences, 4, 3538-3544.

Pankov, R., Endo, Y., Even-Ram, S., Araki, M., Clark, K., Cukierman, E., Matsumoto, K., \& Yamada, K. M. (2005). A Rac switch regulates random versus directionally persistent cell migration. Journal of Cell Biology, 170 (5), 793-802.

Parente, L. M. L., Lino Junior, R. S., Tresvenzol, L. M. F., Vinaud, M. C., De Paula, J. R., \& Paulo, N. M. (2012). Wound healing and anti-inflammatory effect in animal models of Calendula officinalis L. growing in Brazil. Evidence-based Complementary and Alternative Medicine, $11,1-7$.

Parmar, V. S., Jain, S. C., Bisht, S. K., Jain, R., Taneja, P., \& Tyagi, O. D. (1997). Phitochemistry of the genus Piper. Phytochemistry, $46,591-673$.

Passos, F. B., Lopes, C. M., Aquino, F. G., \& Ribeiro, J. F., 2014. Nurse plant effect of Solanum lycocarpum A. St.-Hil. in area of brazilian savanna undergoing a process of restoration. Brazilian Journal of Botany, 37 (3), 251-259.

Peacock Jr., E. E. The wound repair: W B Saunders, 1984. p. 76-85.

Peng, L. H., Fung, K. P., Leung, P. C., \& Gao, J. Q. (2011). Genetically manipulated adult stem cells for wound healing. Drug Discovery Today, 16 (21-22), 957-66.

Peng, L. H., Mao, Z. Y., Qi, X. T., Chen, X., Li, N., Tabata, Y., \& Gao, J. Q. (2013). Transplantation of bone-marrow-derived mesenchymal and epidermal stem cells contribute to wound healing with different regenerative features. Cell and Tissue Research, 352 (3), $573-83$.

Pereira, A. S., Shitsuka, D. M., Parreira, F. J., \& Shitsuka, R. (2018). Metodologia da pesquisa científica. UFSM. https://repositorio.ufsm.br/bitstream /handle/1/15824Lic_Computacao_Metodologia-Pesquisa-Cientifica.pdf?sequence=1

Piriz, M. A., Lima, C. A. B., Jardim, V. M. R., Mesquita, M. K., Souza, A. D. Z., \& Heck, R. M. (2014). Plantas medicinais no processo de cicatrização de feridas: uma revisão de literatura. Revista Brasileira de Plantas Medicinais, 16 (3), 628-636.

Prasad, S., Kalra, N., Singh, M., \& Shukla, Y. (2008). Protective effects of lupeol and mango extract against androgen induced oxidative stress in swiss albino mice. Asian Journal of Andrology, 10, 313-8.

Reddy, G. K., \& Enwemeka, C. S. (1996). A simplified method for the analysis of hydroxyproline in biological tissues. Clinical Biochemistry, 29 (3), $225-229$.

Ribeiro, R. I. M. A., Kuribayashi, J. S., Borges Júnior, P. C., Beletti, M. E., Espindola, F. S., Cassali, G. D., \& Loyola, A. M. (2010). Inhibition of metalloproteinases by Aloe vera, Annona muricata, and black tea aqueous extracts. Journal of Biosciences, 26 (1), $121-127$.

Rovani, G., Santos, V. L. P., Miguel, O. G., Budel, J. M., \& Campos, R. (2013). Investigação fitoquímica e antioxidante de partes vegetativas aéreas de Piper amalago L. Caderno da Escola de Saúde, 2, 164-177. 
Roy, P., Amdekar, S., Kumar, A., Singh, R., Sharma, P., \& Singh, V. (2012). In vivo antioxidative property, antimicrobial and wound healing activity of flower extracts of Pyrostegia venusta (Ker Gawl) Miers. Journal of Ethnopharmacology, 140 (1), 186-192.

Salehi, B., Zakaria, Z. A., Ibrahim, S. A., Rajkovic, J., Shinwari, Z. K., Khan, T., Sharifi-Rad, J., Ozleyen, A., Turkdonmez, E., Valussi, M., Tumer, T. B., Fidalgo, L. M., Martorell, M., \& Setzer, W. N. (2019). Piper species: a comprehensive review on their phytochemistry, biological activities and applications. Molecules, 24 (7), 1364.

Sandhu, S. V., Gupta, S., Bansal, H., \& Singla, K. (2012). Collagen in health and disease. Journal of Orofacial Sciences, 2, 153-159.

Santos, V. L. P., Franco, C. R. C., Amano, E., Messias-Reason, I. J., \& Budel, J. M. (2015). Anatomical investigations of Piper amalago (jaborandi-manso) for the quality control. Revista Brasileira de Farmacognosia, 25 (2), 85-91.

Santos, V. L. P., Lima, C. P., Campos, R., Ribeiro, C. S. R., Marques, F. A., Budel, J. M., \& Messias-Reason, I. J. (2016). Chemical composition and antimicrobial activity of volatile oils of Piper amalago L. Latin American Journal of Pharmacy, 35, 1883-1889.

Santos, V. L. P., Lima, C. P., Campos, R., Budel, J. M., \& Messias-Reason, I. J. (2019). Determination of flavonoids and the antimicrobial activity of leaves of Piper amalago L., Piperaceae. World Journal of Pharmaceutical Science, 8, 1635-1644.

Santos, V. L. P., Lima, C. P., Franco, C. R. C., Monteiro, L. M., Budel, J. M., \& Messias-Reason, I. J. (2020). Determination on the chemical groups in the lyophilized aqueous extract obtained from the leaves of Piper amalago L. World Journal of Pharmaceutical Science, 9 (5), 109-120.

Savino, W., Ayres Martins, S., \& Neves-dos-Santos, S. (2003). Thymocyte migration: an affair of multiple cellular interactions? Brazilian Journal of Medical and Biological Research, 36, 1015-1025.

SEMA. Secretaria Estadual do Meio Ambiente. Departamento de Florestas e áreas Protegidas do Estado do Rio Grande do Sul e Departamentos de Ciências Florestais, Engenharia Rural e Geociências da Universidade Federal de Santa Maria. Relatório Final do Inventário Florestal Contínuo do Rio Grande do Sul. Rio Grande do Sul, 2003.

Silva, P. S. G., Lopes, R. F., Silva, J. C., Santos, W. B., Veríssimo, R. C. S. S., \& Bastos, M. L. A. (2018). Atividade citotóxica, antimicrobiana e cicatrizante do extrato da Jatropha gossypiifolia L. Revista de Enfermagem UFPE, 12 (2), 465-74.

Singh, D., Singh, D., Choi, S. M., Zo, S. M., Painuli, R. M., Kwon, S. W., \& Han, S. S. (2014). Effect of extracts of Terminalia chebula on proliferation of keratinocytes and fibroblasts cells: an alternative approach for wound healing. Evidence-based Complementary and Alternative Medicine, 2014,1 -13.

Soley, B. S., Morais, R. L., Pesquero, J. B., Baderc, M., Otukia, M. F., \& Cabrinia, D. A. (2016). Kinin receptors in skin wound healing. Evidence-based Complementary and Alternative Medicine, 82 (2), 95-105.

Sosa, S., Balick, M. J., Arvigo, R., Esposito, R. G., Pizza, C., Altinier, G., \& Tubaro, A. (2002). Screening of the topical anti-inflammatory activity of some Central American plants. Journal of Ethnopharmacology, 81, 211-5.

Suzuki, A., Angulo, P., Lymp J., Li, D., Satomura, S., \& Lindor, K. (2005). Hyaluronic acid, an accurate serum marker for severe hepatic fibrosis in patients with non-alcoholic fatty liver disease. Liver International, 25, 779-786.

Thakur, R., Jain, N., Pathak, R., \& Sandhu, S. S. (2011). Practices in wound healing studies of plants. Evidence-based Complementary and Alternative Medicine, 2011, 1-17.

Tobin, D. J. (2006). Biochemistry of human skin-our brain on the outside. Chemical Society Reviews, 35, 52-67.

Torres, L. R. O., Santana, F. C., Shinagawa, F. B., \& Mancini Filho, J. (2018). Bioactive compounds and functional potential of pequi (Caryocar spp.), a native brazilian fruit: a review. Grasas y Aceites, 69, 1-16.

Trengove, N. J., Stacey, M. C., Macauley, S., Bennett, N., Gibson, J., Burslem, F., Murphy, G., \& Schultz, G. (1999). Analysis of the acute and chronic wound environments: the role of proteases and their inhibitors. Wound Repair and Regeneration, 7 (6), 442-52.

Tsala, D. E., Amadou, D., \& Habtemariam, S. (2013). Natural wound healing and bioactive natural products. Phytopharmacology, 4 (3), 532-60.

Varga, E., Bardocz, A., Belak A., Maraz, A., Boros, B., Felinger, A., Böszörmenyi, A., \& Horvath, G. (2015). Antimicrobial activity and chemical composition of thyme essential oils and the polyphenolic content of different Thymus extracts. Farmacia, 63 (3), 357-361.

Vallenius, T. (2013). Actin stress fibre subtypes in mesenchymal-migrating cells. Biology Open, 3 (6), 1-10.

Vancheri, C., Gili, E., \& Failla, M. (2005). Bradykinin differentiates human lung fibroblasts to a myofibroblast phenotype via the B2 receptor. The Journal of Allergy and Clinical Immunology, 116, 1242-1248.

Viana, P. A., Prates, H. T., \& Ribeiro, P. E. A. (2006). Uso do extrato aquoso de folhas de nim para o controle de Spodoptera frugiperda no milho. Sete Lagoas: Embrapa Milho e Sorgo.

Vieira, A. P., Santos, N. R., Borges, J. H. S., Vincenzi, M. P. A., \& Schmitz, W. O. (2008). Ação dos flavonóides na cicatrização por segunda intenção em feridas limpas induzidas cirurgicamente em ratos Wistar. Semina: Ciências Biológicas e da Saúde, 29 (1), 65-74.

Visse, R., \& Nagase, H. (2003). Matrix metalloproteinases and tissue inhibitors of metalloproteinases: structure, function and biochemistry. Circulation Research, 92 (8), 827-839. 